\title{
C-5 Hydroxyethyl and Hydroxypropyl Acyclonucleosides as Substrates for Thymidine Kinase of Herpes Simplex Virus Type 1 (HSV-1 TK): Syntheses and Biological Evaluation
}

Andrijana Meščić ${ }^{1}$, Svjetlana Krištafor ${ }^{1}$, Ivana Novaković ${ }^{2}$, Amar Osmanović ${ }^{3}$, Ursina Müller ${ }^{4}$, Davorka Završnik ${ }^{3}$, Simon M. Ametamey ${ }^{4}$, Leonardo Scapozza ${ }^{2}$ and Silvana Raić-Malić ${ }^{1, *}$

1 Department of Organic Chemistry, Faculty of Chemical Engineering and Technology, University of Zagreb, Marulićev trg 20, HR-10000 Zagreb, Croatia;

E-Mails: amescic@fkit.hr (A.M.); prekupec@fkit.hr (S.K.)

2 Pharmaceutical Biochemistry, School of Pharmaceutical Sciences, University of Geneva, Quai Ernest-Ansermet 30, CH-1211 Geneva 4, Switzerland;

E-Mails: Ivana.Novakovic@unige.ch (I.N.); Leonardo.Scapozza@unige.ch (L.S.)

3 Department of Pharmaceutical Chemistry, Faculty of Pharmacy, University of Sarajevo, Zmaja od Bosne 8, BIH-71 000 Sarajevo, Bosnia and Herzegovina;

E-Mails: amkooo@hotmail.com (A.O.); dzavrsnik@yahoo.com (D.Z.)

4 Center for Radiopharmaceutical Sciences, ETH Zurich (Swiss Federal Institute of Technology), Wolfgang-Pauli Strasse 10, CH-8093 Zurich, Switzerland;

E-Mails: ursinamuller@gmail.com (U.M.); simon.ametamey@pharma.ethz.ch (S.M.A.)

* Author to whom correspondence should be addressed; E-Mail: sraic@fkit.hr;

Tel.: +385-1-4597-213; Fax: +385-1-4597-224.

Received: 31 January 2013; in revised form: 16 April 2013 / Accepted: 25 April 2013 /

Published: 2 May 2013

\begin{abstract}
The efficient syntheses of 5-(2-hydroxyethyl)- and 5-(3-hydroxypropyl)substituted pyrimidine derivatives bearing 2,3-dihydroxypropyl, acyclovir-, ganciclovirand penciclovir-like side chains are reported. A synthetic approach that included the alkylation of an $\mathrm{N}$-anionic-5-substituted pyrimidine intermediate (method A) provided the target acyclonucleosides in significantly higher overall yields in comparison to those obtained by method B using sylilation reaction. The phosphorylation assays of novel compounds as potential substrates for thymidine kinase of herpes simplex virus type 1 (HSV-1 TK) showed that solely pyrimidine 5-substituted acyclonucleosides with a penciclovir-like side chain acted as a fraudulent substrates of HSV-1 TK. Moreover, the uracil derivative with penciclovir-like side chain with less bulky 2-hydroxyethyl
\end{abstract}


substituent at C-5 proved to be a better substrate than the corresponding one with a 3-hydroxypropyl substituent. Therefore, this acyclonucleoside was selected as a lead compound for the development of a positron emission tomography HSV-1 TK activity imaging agent.

Keywords: acyclic nucleoside analogues; 5-substituted pyrimidines; herpes simplex virus type 1 thymidine kinase (HSV-1 TK); positron emission tomography (PET)

\section{Introduction}

Nucleoside analogues have acquired an important role as therapeutic agents in the field of chemotherapy on account of their extensive biological activities [1,2]. Thereby, modified nucleosides and nucleobases are a pharmacologically diverse family, which includes anticancer compounds, antiviral agents, and immunosuppressive molecules. Interest in acyclic nucleosides began in the mid1970s when acyclovir was first reported as a potent anti-herpes drug [3,4]. Many variations, both of the acyclic glycone and of the heterocyclic base, have been described [5,6]. Antiviral nucleoside analogues are known to localize selectively in herpes simplex virus (HSV)-infected cells because of monophosphorylation catalyzed by virus-encoded thymidine kinase (TK) [7]. Among these, acyclovir, ganciclovir and penciclovir are reported to be potent against HSV types 1 and $2[8,9]$ (Figure 1).

Figure 1. Acyclic nucleoside analogues and 2'-deoxyuridines as chemotherapeutic agents.

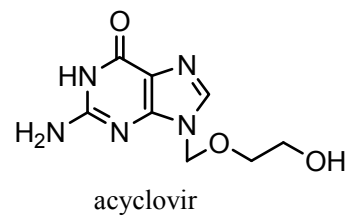

acyclovir

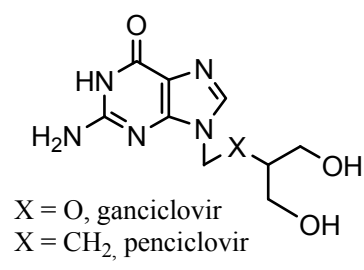

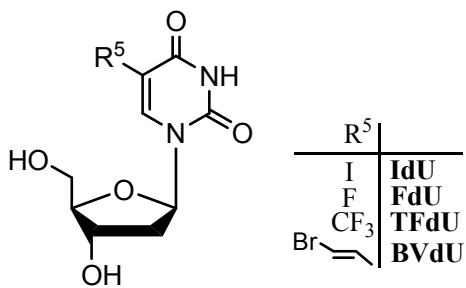

In another area, a great number of 5-substituted uracil derivatives, especially 2'-deoxyuridines, have been investigated for the experimental and clinical treatment of neoplastic and viral diseases (Figure 1). The selective monophosphorylation of antiviral nucleoside analogues by virus-encoded thymidine kinase has been exploited in gene therapy of cancer [10]. Gene therapy offers promising new treatment modalities in oncology and other diseases [11]. The suicide gene, HSV-1 TK, has already been successfully employed in a variety of tumour models, both in vitro and in vivo [12,13]. A prodrug with low toxicity becomes toxic only in cells where the HSV-1 TK gene is expressed, thus resulting in the selective killing of transfected cells through termination of DNA synthesis. Phosphorylation of radioactive-labelled prodrugs, usually derivatives of acyclonucleosides which are selective anti-herpes agents, leads to metabolites trapped within the infected tumour cells, and the resulting accumulation of radioactivity allows monitoring of the enzyme activity with positron emission tomography (PET) [14-16]. A striking difference is that while all pyrimidine nucleoside analogues show low, if any, bystander killing effects, purine derivatives such as ganciclovir are endowed with bystander killer effect [17]. 
As found earlier, pyrimidine nucleoside analogues in which the acyclic sugar moiety is attached at the $\mathrm{C}-6$ rather than at the $\mathrm{N}-1$ position have the potential for the development as a new PET imaging probe. Therefore, thymines with 6-(2,3-dihydroxypropyl), 6-(1,3-dihydroxyisobutyl) and 6-(1,3dihydroxyisobutenyl) side chains have been developed as tracer molecules for monitoring HSV-1 TK expression by means of PET [18-20]. Although the $N$-methylated thymine derivative, $N$-Me[18F]FHBT, bearing a 1,3-dihydroxyisobutyl side-chain at the C-6 position was not superior to the purine analogue $[18 \mathrm{~F}] \mathrm{FHBG}$, an established PET reporter probe for imaging HSV-1 TK expression, $N$-Me-[18F]FHBT clearly showed the feasibility of its use as a PET probe to monitor HSV-1 TK gene expression in vivo [21].

In an effort to further explore the pyrimidine scaffold as a putative starting point for the development of new fraudulent substrates of HSV-1 TK for non-invasive imaging of HSV-1 TK gene expression with improved pharmacodynamic and pharmacokinetic profile, we have synthesized a series of novel 5-substituted acyclic nucleoside analogues. Here we report on the synthesis of target 5-(2-hydroxyalkyl)-substituted uracil derivatives bearing 2,3-dihydroxypropyl (19), acyclovir- (21), ganciclovir- (23) and penciclovir-like (31 and 32) substituents at $\mathrm{N}-1$ position of the pyrimidine ring (Figure 2). In order to evaluate target nucleoside mimetics 19, 21, 23, 31 and 32 as substrates for HSV-1 TK, molecular modelling and phosphorylation assays of these compounds were performed.

Figure 2. Novel 5-(2-hydroxyalkyl)-substituted uracil derivatives bearing 2,3-dihydroxypropyl (19), acyclovir- (21), ganciclovir- (23) and penciclovir-like (31 and 32) side chains.

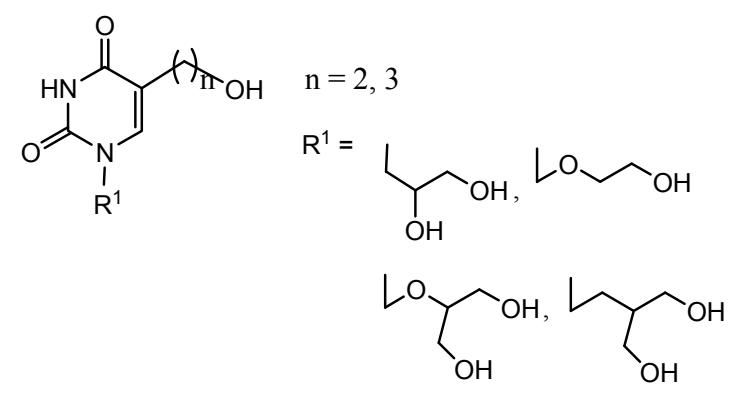

\section{Results and Discussion}

\subsection{Chemistry}

5-(2-Hydroxyalkyl)uracil derivatives with 2,3-dihydroxypropyl (19), acyclovir- (21), ganciclovir(23) and penciclovir-like (31 and 32) side chains were prepared from the corresponding uracil derivatives 10 and 14-16 by the methods outlined in Schemes 1-3. The synthesis of compounds 10 and 14-16, as precursors for $N$-alkylation, was performed in excellent yields (80-99\%) (Scheme 1). 5-(2-Hydroxyethyl)- and 5-(3-hydroxypropyl)-substituted uracils $\mathbf{1}$ and $\mathbf{2}$ served as starting materials and their syntheses were reported earlier [22-24]. The synthesis of 5-substituted 2,4-dimethoxypyrimidine derivatives 10 and 11 was carried out by acetylation, chlorination at the positions C-2 and C-4 with $\mathrm{POCl}_{3}$, methoxylation with sodium methoxide and repeated acetylation [25] (Scheme 1). 
Scheme 1. Synthesis of the precursors 10 and 14-16 for $N$-alkylation.

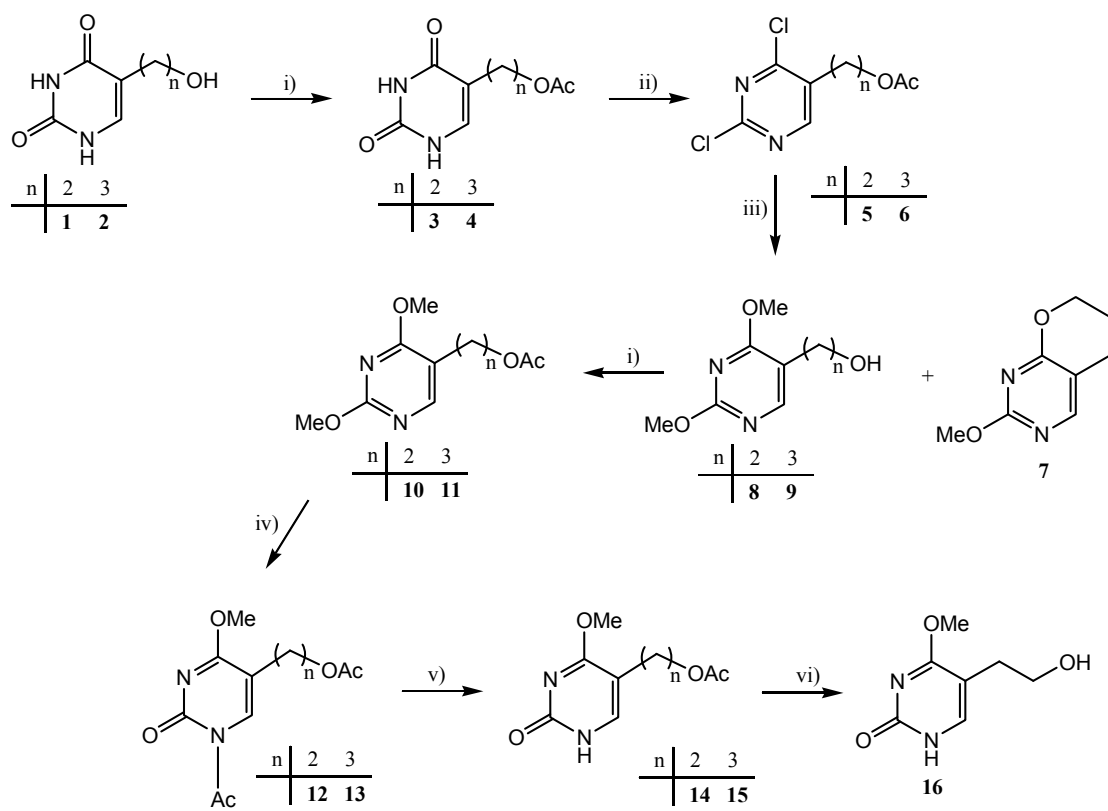

Reagents and conditions: (i) acetic anhydride, pyridine, rt, 1 h; (ii) $\mathrm{POCl}_{3}, N, N$-diethylaniline, pyridine, reflux, $1 \mathrm{~h}$; (iii) $\mathrm{NaOMe} / \mathrm{MeOH}, \mathrm{rt}, 20 \mathrm{~h}$; (iv) $\mathrm{AcCl}, \mathrm{rt}, 20 \mathrm{~h}$; (v) silica gel column chromatography; (vi) $\mathrm{NaOMe} / \mathrm{MeOH}, \mathrm{rt}, 1 \mathrm{~h}$.

Selective 2-dealkylation of 5-(acetoxyalkyl)-2,4-dimethoxypyrimidines [26] $\mathbf{1 0}$ and $\mathbf{1 1}$ in non-aqueous acid gave the corresponding 4-methoxypyrimidin-2-one derivatives 14 and $\mathbf{1 5}$. Treatment of the acetyl protected 2,4-dimethoxypyrimidines $\mathbf{1 0}$ and $\mathbf{1 1}$ with acetyl chloride afforded $\mathrm{N}$-acetylated 4-methoxypyrimidin-2-one derivatives 12 and $\mathbf{1 3}$, which after $\mathrm{N}$-deprotection and purification using column chromatography on silica gel yielded 14 and 15 (Scheme 1). Final deacetylation of $\mathbf{1 4}$ gave 4-methoxypyrimidin-2-one 16 with a 2-hydroxyethyl substituent at C-5.

Further synthetic steps in the preparation of target compounds 19, 21 and 23 involved $\mathrm{N}$-alkylation applied by two synthetic methods (A and B, Scheme 2, Table 1). In order to ensure the introduction of the substituent into position N-1 of the pyrimidine ring, the Hilbert-Johnson reactions [27] were applied in synthetic method A. These reactions involved the treatment of 5-(2-acetoxyethyl)-2,4dimethoxypyrimidine derivative $\mathbf{1 0}$ with alkyl halides. Allyl bromide and 1,3-dibenzyloxy-2chloromethoxypropane [28] were used as agents for the introduction of 2,3-dihydroxypropyl (in 19) and ganciclovir-like side chain (in 23), respectively. Furthermore, the treatment of 1,3-dioxolane with acetyl bromide gave (2-acetoxyethoxy)methyl bromide [29] as a readily distilled colourless oil, which served as the alkylating reagent for the introduction of the acyclovir-like side chain (in 21). Unlike alkylation with allyl bromide which gave $N$-1-substituted 4-methoxypyrimidine 17 in $73 \%$ yield, alkylation using (2-acetoxyethoxy)methyl bromide and 1,3-dibenzyloxy-2-chloromethoxypropane was accompanied by 4-demethylation and the corresponding $\mathrm{N}$-1-substituted pyrimidin-2,4-dione derivatives $\mathbf{2 0}$ and $\mathbf{2 2}$ were isolated in moderate yield (43\% and 36\%, respectively). 
Scheme 2. Synthesis of 5-(2-hydroxyethyl)uracil derivatives with 2,3-dihydroxypropyl (19), acyclovir- (21) and ganciclovir-like (23) side chain.

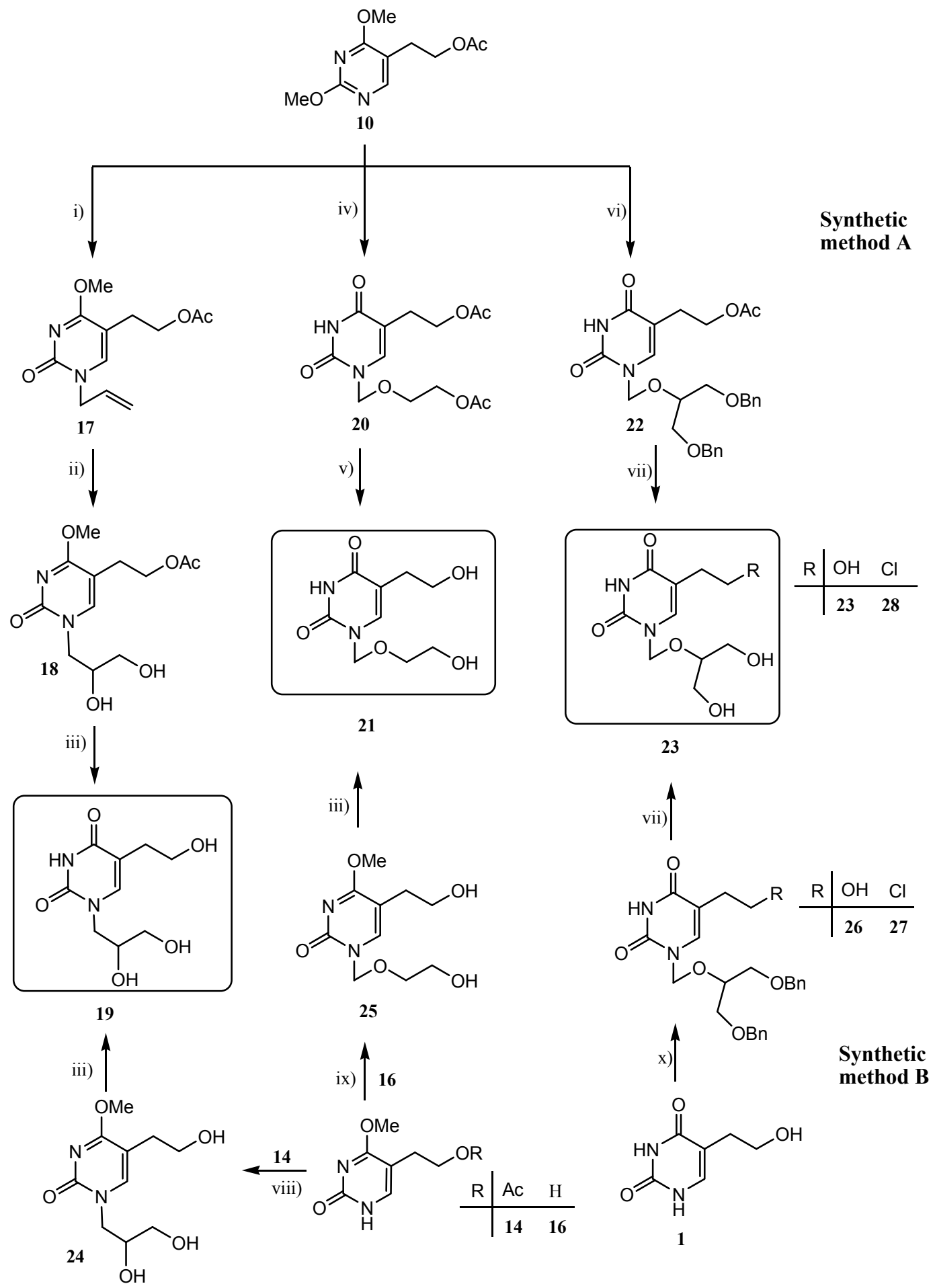

Reagents and conditions: (i) allyl bromide; (ii) $\mathrm{NaClO}_{3}, \mathrm{OsO}_{4}$; (iii) $1 \mathrm{M} \mathrm{NaOH}$, rt, $20 \mathrm{~h}$; (iv) (2-acethoxyethoxy)methyl bromide, $\mathrm{Na}_{2} \mathrm{CO}_{3}$, rt, 24 h; (v) NaOMe/MeOH, rt, 20 h; (vi) 1,3-dibenzyloxy-2chloromethoxypropane, $\mathrm{K}_{2} \mathrm{CO}_{3}, \mathrm{CH}_{2} \mathrm{Cl}_{2}, \mathrm{rt}, 24 \mathrm{~h}$; (vii) $\mathrm{BCl}_{3}, \mathrm{CH}_{2} \mathrm{Cl}_{2}, 3 \mathrm{~h}$; (viii) $\mathrm{NaH}$, DMF, 1-chloro-2,3dihydroxypropane; (ix) $\mathrm{BSA}, \mathrm{CH}_{3} \mathrm{CN}$, dioxolane, $\mathrm{KI}, \mathrm{TMSCl}, \mathrm{rt}, 48 \mathrm{~h}$; (x) 1. HMDS, TMSCl; 2. 1,3-dibenzyloxy-2-chloromethoxypropane, TBAI, $\mathrm{CH}_{3} \mathrm{CN}, \mathrm{rt}, 24 \mathrm{~h}$. 
Table 1. An overview of the yields in synthetic method A and B for target compounds 19, 21 and 23.

\begin{tabular}{|c|c|c|c|c|}
\hline \multirow{2}{*}{\multicolumn{2}{|c|}{ Synthetic method A }} & 19 & 21 & 23 \\
\hline & & \multicolumn{3}{|c|}{ Yields } \\
\hline 1. & Acetylation & $98 \%$ & $98 \%$ & $98 \%$ \\
\hline 2. & Chlorination & $99 \%$ & $99 \%$ & $99 \%$ \\
\hline 3. & Methoxylation & $95 \%$ & $95 \%$ & $95 \%$ \\
\hline 4. & Acetylation & $90 \%$ & $90 \%$ & $90 \%$ \\
\hline 5. & Alkylation/Hydroxylation & $73 \% / 50 \%$ & $43 \%$ & $36 \%$ \\
\hline \multirow[t]{2}{*}{6.} & Deprotection & $39 \%$ & $74 \%$ & $67 \%$ \\
\hline & Overall yield: & $12 \%$ & $26 \%$ & $20 \%$ \\
\hline \multirow{2}{*}{\multicolumn{2}{|c|}{ Synthetic method B }} & 19 & 21 & 23 \\
\hline & & \multicolumn{3}{|c|}{ Yields } \\
\hline 1. & Acetylation & $98 \%$ & $98 \%$ & - \\
\hline 2. & Chlorination & $99 \%$ & $99 \%$ & - \\
\hline 3. & Methoxylation & $95 \%$ & $95 \%$ & - \\
\hline 4. & Acetylation & $90 \%$ & $90 \%$ & - \\
\hline 5. & Demethoxylation & $80 \%$ & $80 \%$ & - \\
\hline 6. & Deacetylation & - & $93 \%$ & - \\
\hline 7. & Silylation/Akylation & $75 \%$ & $25 \%$ & $8 \%$ \\
\hline \multirow[t]{2}{*}{8.} & Deprotection & $37 \%$ & $26 \%$ & $65 \%$ \\
\hline & Overall yield: & $18 \%$ & $4 \%$ & $5 \%$ \\
\hline
\end{tabular}

cis-Dihydroxylation of $\mathrm{N}$-1-allyl pyrimidine derivative 17 with sodium chlorate in the presence of osmium tetroxide afforded $N$-1-(2,3-dihydroxypropyl)pyrimidine derivative $\mathbf{1 8}$ which after the 4-demethylation and deacetylation with sodium hydroxide yielded the desired 5-(2hydroxyethyl)pyrimidine 19 bearing a 2,3-dihydroxypropyl group at $\mathrm{N}-1$. The overall yield of this method was $12 \%$. The deacetylation of the side chains at C-5 and N-1 of $\mathbf{2 0}$ under basic conditions afforded the 5-(2-hydroxyethyl)pyrimidine 21 with the best overall yield of $26 \%$. Similarly, both deacetylation in C-5 and debenzylation in N-1 side chains of 22 using boron trichloride gave the 5-(2hydroxyethyl)-substituted pyrimidine $\mathbf{2 3}$ with a ganciclovir-like side chain at $\mathrm{N}-1$.

In search for a more efficient synthesis of 19, an alternate method B was applied using sodium hydride as deprotonating agent and thus the uracil salt obtained in situ reacted with 1-chloro-2,3dihydroxypropane to give trihydroxy 4-methoxypyrimidin-2-one 24. Deprotection of 24 yielded target the trihydroxypyrimidin-2,4-dione 19. In comparison to synthetic method A this method for preparation of $\mathbf{1 9}$ is more efficient and the use of the highly poisonous reagent osmium tetroxide for cis-hydroxylation was avoided. Similarly, compounds 21 and 23 were also prepared by silylation reactions (synthetic method B). Since silylation of 5-(2-hydroxyethyl)uracil (1) using N,O-bis(trimethysilyl)acetamide (BSA) was unsuccessful, pyrimidin-2-one 16 was used for $N$-alkylation. Trimethylsilylation of 16 [26] using BSA and in situ coupling employing trimethylchlorosilane, potassium iodide and 1,3-dioxolane in dry acetonitrile was performed, and the expected product $\mathbf{2 1}$ was obtained after hydrolysis of $\mathbf{2 5}$ with sodium hydroxide (Scheme 2). Furthermore, compound $\mathbf{2 3}$ was prepared directly from 5-(2-hydroxyethyl)uracil (1) by the silylation of $\mathbf{1}$ and in situ reaction of O-persilylated 1 with 1,3-dibenzyloxy-2-chloromethoxypropane to give $\mathrm{N}$-1-alkylated pyrimidine $\mathbf{2 6}$ 
in $8 \%$ yield (method B). The removal of the benzyl protecting groups in $\mathbf{2 6}$ proceeded smoothly and led to target compound 23.

For the introduction of a penciclovir-like side chain at $\mathrm{N}-1$ position of the pyrimidine ring, 4-acetoxy-(3-acetoxymethyl)butyl iodide [30,31], prepared from a mesylate and the related bromide, was used. Since neither direct Hilbert-Johnson-type reaction of 2,4-dimethoxypyrimidine derivative 10 with both alkyl halides and mesylate did not yield the corresponding pyrimidine acyclonucleoside, an alternative method using 4-methoxypyrimidin-2-one derivatives 14 and 15 was applied.

Thus, the reaction of potassium salts of $\mathbf{1 4}$ and $\mathbf{1 5}$ with 4-acetoxy-(3-acetoxymethyl)butyl iodide led to the target 5-(2-hydroxyethyl)- $\mathbf{3 1}$ and 5-(3-hydroxypropyl)pyrimidine $\mathbf{3 2}$ bearing a penciclovir-like side chain (Scheme 3).

Scheme 3. Synthesis of 5-(2-hydroxyalkyl)uracil derivatives $\mathbf{3 1}$ and $\mathbf{3 2}$ with penciclovir-like side chains.

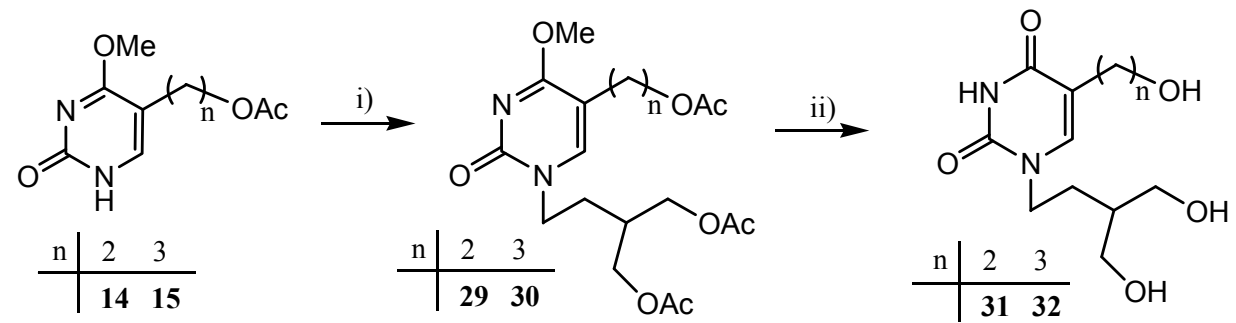

Reagents and conditions: (i) 4-Acetoxy-(3-acetoxymethyl)butyl iodide, $\mathrm{K}_{2} \mathrm{CO}_{3}, \mathrm{DMF}, 60{ }^{\circ} \mathrm{C}, 20 \mathrm{~min}$; (ii) $1 \mathrm{M}$ $\mathrm{NaOH}, \mathrm{rt}, 20 \mathrm{~h}$.

\subsection{In Vitro Validation of Compounds 19, 21, 23, 31 and 32 as Substrates of HSV-1 TK and hTK}

To determine whether compounds 19, 21, 23, 31 and $\mathbf{3 2}$ are substrates of HSV-1 TK or human TK, phosphorylation assays were performed by incubation of deoxythymidine (dT) and target compounds with recombinant HSV-1 TK and human TK (hTK) according to a previously published protocol [32]. The monophosphorylation was monitored qualitatively by the formation of new peaks corresponding to adenosine diphosphate (ADP), monophosphate derivatives of tested compounds and thymidine monophosphate (dTMP). Results of phosphorylation assays for 19, 21 and 23 indicated that these compounds are not phosphorylated by either HSV-1 TK or human TK (see Supplementary Materials). While acyclonucleosides containing dihydroxypropyl (19), acyclovir- (21) and ganciclovir-like side chain (23) were not phosphorylated, both 5-substituted acyclic pyrimidines $\mathbf{3 1}$ and $\mathbf{3 2}$ with a penciclovir-like side chain showed to be substrates of HSV-1 TK. Furthermore, small alteration in structures of 23, such as replacement of oxygen in the (1,3-dihydroxy-2-propoxy)methyl side chain at N-1 with a methylene group (compound 31), has an impact on phosphorylation reaction of these compounds. We can assume that the electron donating oxygen has an influence on the interaction of $\mathbf{2 3}$ and HSV-1 TK disabling the enzyme to phosphorylate fraudulent substrate $\mathbf{2 3}$ with a ganciclovir-like side chain. Therefore, for compounds $\mathbf{3 1}$ and $\mathbf{3 2}$ while using viral HSV-1 TK, the formation of monophosphate derivatives 31-MP (Figure 3) and 32-MP (Figure 4) as well as ADP were detected, confirming that $\mathbf{3 1}$ and $\mathbf{3 2}$ are substrates of viral HSV-1 TK. However, the size of the alkyl substituent at C-5 exhibited some effect on phosphorylation. Thus, compound $\mathbf{3 1}$ with a less bulky 2-hydroxyethyl 
substituent at C-5 had a higher ADP/ATP ratio compared to compound 32, thus proving to be a better substrate than 32. Furthermore, formation of 31-MP and 32-MP was proven by extracting the max. absorbance wavelength of the new appearing peaks which corresponds to the max. absorbance wavelength of compounds 31 and 32 (Figures 3 and 4). No phosphorylation was observed for compounds 31 and 32 when human TK was used, indicating that these two compounds are not substrates for hTK.

Figure 3. HPLC and DAD/HPLC chromatograms of the reaction of $\mathbf{3 1}$ and HSV-1 TK.

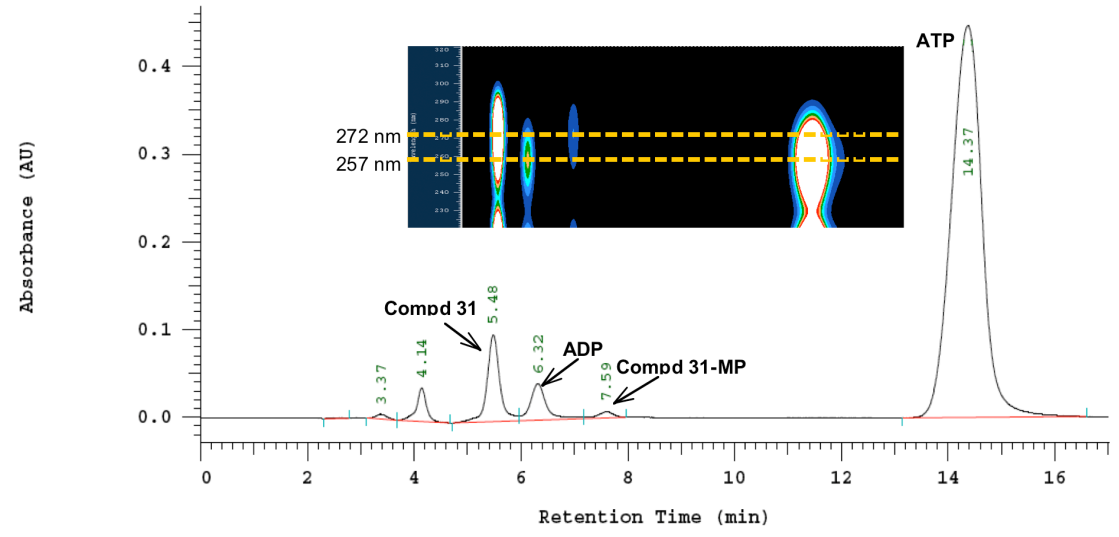

Figure 4. HPLC and DAD/HPLC chromatograms of the reaction of 32 and HSV-1 TK.

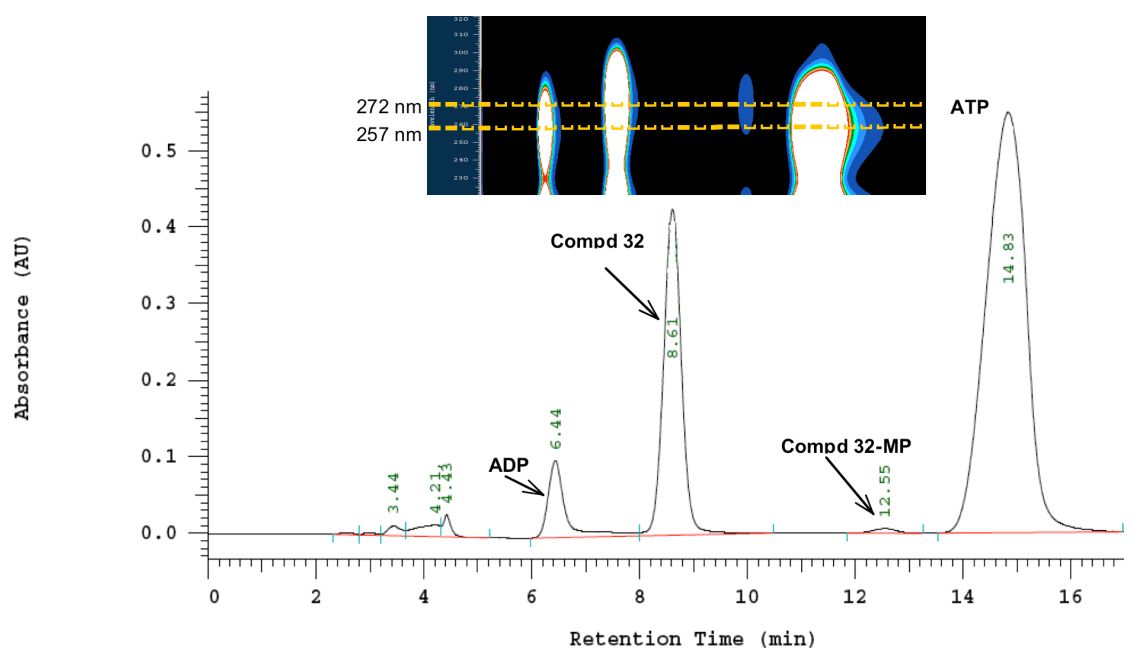

The phosphorylation patterns of compounds $\mathbf{3 1}$ and $\mathbf{3 2}$ by HSV-1 TK and hTK are presented in Figure 5a. No significant difference in ADP/ATP ratio was noticed in phosphorylation assays with hTK.

Phosphorylation reaction of compound $\mathbf{3 1}$ and its fluorinated structural analogue, in which hydroxyl group in C-5 substituent is replaced with fluorine, was performed at 30, 60 and 90 min of incubation (Figure 5b). It is evident that formation of monophosphated derivatives for both compounds was increased over time. By comparison of calculated values for monophosphated derivatives which were formed at different times (30, 60 and $90 \mathrm{~min})$, we can estimate that approximately 40\% of 31-MP was formed in $30 \mathrm{~min}$ and majority of 31-MP $(\sim 80 \%)$ in $60 \mathrm{~min}$ of incubation. On the contrary, fluorinated derivative gave majority of corresponding monophosphate $(\sim 70 \%)$ already in $30 \mathrm{~min}$ and was almost completely monophosphorylated in $60 \mathrm{~min}$. The synthesis of fluorinated derivative of $\mathbf{3 1}$ and in vivo 
results on small animal PET studies of ${ }^{18} \mathrm{~F}$ labeled compound 31, HHB-5-[18F]FEP, will be presented elsewhere.

Figure 5. (a) Phosphorylation pattern of $1 \mathrm{mM}$ of compounds 31 and 32, by HSV-1 TK and hTK, and of compound $\mathbf{2 3}$ and dT by HSV-1 TK. Blank refers to the control experiment performed in presence of the enzyme and in absence of the compound; (b) Time course for conversion of $\mathbf{3 1}$ and its fluorinated analogue to corresponding monophosphated derivatives.

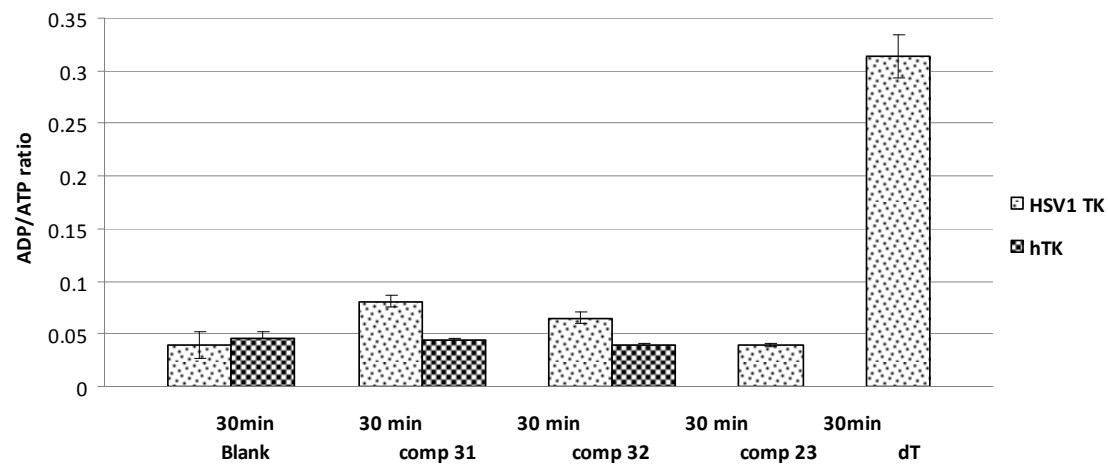

(a)

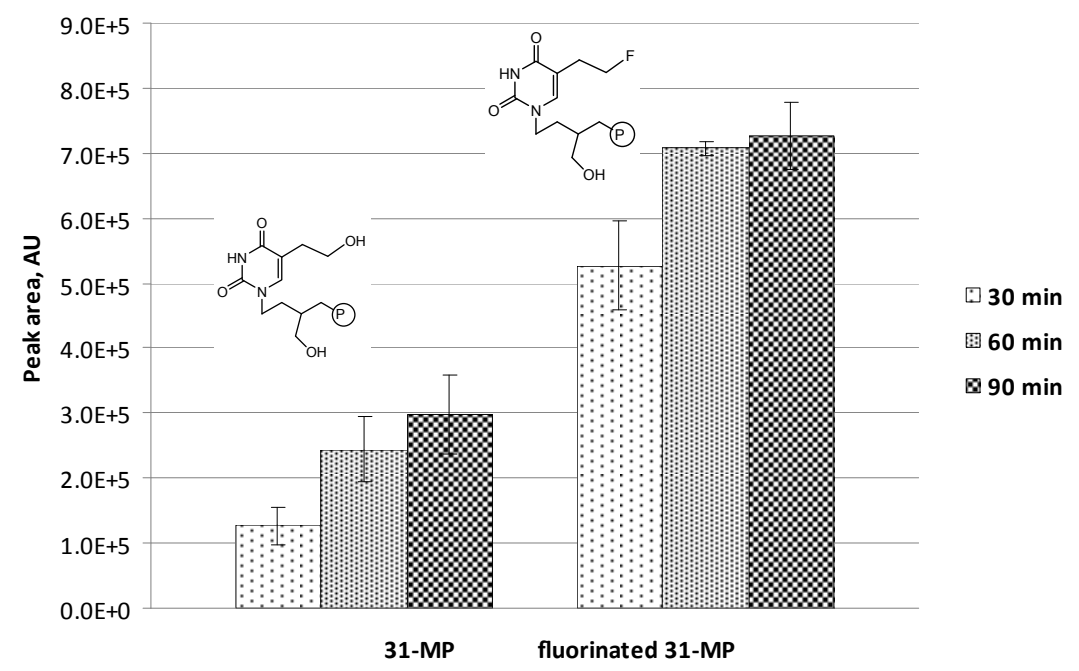

(b)

\subsection{Cellular Activity Evaluation}

Compounds 17-32 were evaluated for their cytotoxic activity against normal human fibroblasts (WI38). The results indicated that the target compounds exhibited no cytotoxic effects against normal human fibroblasts up to $100 \mu \mathrm{M}$.

\section{Experimental}

\subsection{General}

Melting points (uncorrected) were determined with a Kofler micro hot-stage (Reichert, Wien, Austria). Precoated Merck (Darmstadt, Germany) silica gel 60F-254 plates were used for thin layer 
chromatography and the spots were detected under UV light $(254 \mathrm{~nm})$. Column chromatography was performed using Fluka (Buchs, Switzerland) silica gel $(0.063-0.2 \mathrm{~mm})$; glass columns were slurry-packed under gravity. ${ }^{1} \mathrm{H}$ - and ${ }^{13} \mathrm{C}$-NMR spectra were acquired on a Bruker $300 \mathrm{MHz} \mathrm{NMR}$ spectrometer (Bruker Biospin, Rheinstetten, Germany) All data were recorded in DMSO- $d_{6}$ at $298 \mathrm{~K}$. Chemical shifts were referenced to the residual solvent signal of DMSO at $\delta 2.50 \mathrm{ppm}$ for ${ }^{1} \mathrm{H}$ and $\delta$ $39.50 \mathrm{ppm}$ for ${ }^{13} \mathrm{C}$. Individual resonances were assigned on the basis of their chemical shifts, signal intensities, multiplicity of resonances and $\mathrm{H}-\mathrm{H}$ coupling constants. Mass spectra were recorded on an Agilent 6410 instrument (Agilent Technologies, Wilmington, DE, USA) equipped with an electrospray interface and triple quadrupole analyzer (LC/MS/MS). High performance liquid chromatography was performed on an Agilent 1100 series system with UV detection (photodiode array detector) using a Zorbax C18 reverse-phase analytical column $(2.1 \times 30 \mathrm{~mm}, 3.5 \mu \mathrm{m})$. All compounds used for biological evaluation showed $>95 \%$ purity in this HPLC system.

\subsection{Procedures for the Preparation of Compounds}

5-(2-Hydroxyethyl)pyrimidin-2,4-dione (1), 5-(3-hydroxypropyl)pyrimidin-2,4-dione (2), 5-(2acetoxyethyl)pyrimidin-2,4-dione (3), 5-(2-acetoxyethyl)-2,4-dichloropyrimidine (5), 5-(2-hydroxyethyl)-2,4-dimethoxypyrimidine (8), 5-(2-acetoxyethyl)-2,4-dimethoxypyrimidine (10), 5-(2-acetoxyethyl)-4-methoxypyrimidin-2-one (14) and 5-(2-hydroxyethyl)-4-methoxypyrimidin-2-one (16) were synthesized in accord with original procedures given in the literature [22-26].

5-(3-Acetoxypropyl)pyrimidin-2,4-dione (4). The mixture of compound 2 (30 g, $0.18 \mathrm{~mol})$ and acetic anhydride $(138 \mathrm{~mL}, 1.46 \mathrm{~mol})$ in anhydrous pyridine $(327 \mathrm{~mL})$ was stirred at room temperature for $1 \mathrm{~h}$. The reaction was quenched with water and the mixture was evaporated to dryness. After column chromatography $\left(\mathrm{CH}_{2} \mathrm{Cl}_{2}-\mathrm{CH}_{3} \mathrm{OH}=8: 1\right)$ white crystals of compound 4 were isolated $(35.14 \mathrm{~g}, 94 \%$, m.p.: 224-227 $\left.{ }^{\circ} \mathrm{C}\right) .{ }^{1} \mathrm{H}-\mathrm{NMR}:(\delta) 11.00(1 \mathrm{H}, \mathrm{s}, \mathrm{NH}), 10.64(1 \mathrm{H}, \mathrm{s}, \mathrm{NH}), 7.23(1 \mathrm{H}, \mathrm{s}, \mathrm{H}-6), 3.97(2 \mathrm{H}, \mathrm{t}$, H-3', $J=6.5 \mathrm{~Hz}), 2.21\left(2 \mathrm{H}, \mathrm{t}, \mathrm{H}-1^{\prime}, J=7.3 \mathrm{~Hz}\right), 2.00\left(3 \mathrm{H}, \mathrm{s}, \mathrm{COCH}_{3}\right), 1.77-1.64\left(2 \mathrm{H}, \mathrm{m}, \mathrm{H}-2^{\prime}\right)$ ppm.

${ }^{13} \mathrm{C}-\mathrm{NMR}:(\delta) 170.9\left(\mathrm{COCH}_{3}\right), 164.9$ (C-4), 151.8 (C-2), 138.6 (C-6), 111.5 (C-5), 63.7 (C-3'), 27.5 $\left(\mathrm{C}-2^{\prime}\right), 23.2\left(\mathrm{C}-1^{\prime}\right), 21.2\left(\mathrm{CO}^{-} H_{3}\right)$ ppm. MS (ESI): $m / z=213.1\left([M+\mathrm{H}]^{+}\right)$.

5-(3-Acetoxypropyl)-2,4-dichloropyrimidine (6). The mixture of compound 4 (34 g, $0.16 \mathrm{~mol}), \mathrm{POCl}_{3}$ $(320 \mathrm{~mL})$ and $N, N$-diethylaniline $(32 \mathrm{~mL})$ was refluxed for $1 \mathrm{~h}$. The solvent was evaporated to dryness, the residue was diluted with $\mathrm{CCl}_{4}(300 \mathrm{~mL})$, washed twice with iced water and dried over $\mathrm{MgSO}_{4}$. After the removal of the solvent, compound 6 (34.87 g, 87\%) was isolated as a yellow oil. ${ }^{1} \mathrm{H}-\mathrm{NMR}$ :

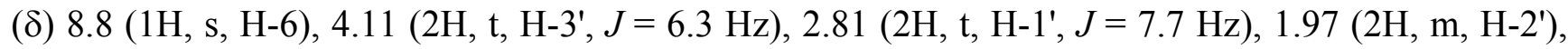
$2.01\left(3 \mathrm{H}, \mathrm{s}, \mathrm{COCH}_{3}\right)$ ppm. ${ }^{13} \mathrm{C}-\mathrm{NMR}:(\delta) 170.1\left(\mathrm{COCH}_{3}\right), 161.2(\mathrm{C}-4), 161.1(\mathrm{C}-2), 156.5(\mathrm{C}-6), 132.4$ (C-5), $62.8\left(\mathrm{C}-3^{\prime}\right), 26.9\left(\mathrm{C}-2^{\prime}\right), 25.6\left(\mathrm{C}-1^{\prime}\right), 20.4\left(\mathrm{COC}_{3}\right) \mathrm{ppm}$. MS (ESI): $m / z=250.1\left([\mathrm{M}+\mathrm{H}]^{+}\right)$.

2-Methoxy-6,7-dihydro-5H-pyrano[2,3-d]pyrimidine (7) and 2,4-dimethoxy-5-(3-hydroxypropyl)pyrimidine (9). To a solution of sodium $(16.7 \mathrm{~g}, 0.72 \mathrm{~mol})$ in anhydrous methanol $(703 \mathrm{~mL})$ compound 6 (34.87 g, $0.14 \mathrm{mmol}$ ) was added. The reaction mixture was stirred at room temperature for $20 \mathrm{~h}$, neutralized with ether saturated with gaseous $\mathrm{HCl}$ at $0{ }^{\circ} \mathrm{C}$. The solvent was evaporated and $\mathrm{CHCl}_{3}$ $(560 \mathrm{~mL})$ was added. The mixture was stirred at room temperature for $20 \mathrm{~h}$ and filtered. The filtrate 
was dried over $\mathrm{MgSO}_{4}$ and evaporated to dryness. After column chromatography $\left(\mathrm{CH}_{2} \mathrm{Cl}_{2}-\mathrm{CH}_{3} \mathrm{OH}=\right.$ 35:1) compounds $7\left(9.66 \mathrm{~g}, 42 \%\right.$, m.p.: $\left.68-70{ }^{\circ} \mathrm{C}\right)$ and $9(5.29 \mathrm{~g}, 19 \%)$ were isolated.

7: ${ }^{1} \mathrm{H}-\mathrm{NMR}:(\delta) 8.15$ (1H, s, H-6), $4.32(2 \mathrm{H}, \mathrm{t}, \mathrm{H}-3$ ', $J=5.2 \mathrm{~Hz}), 3.79\left(3 \mathrm{H}, \mathrm{s}, \mathrm{OCH}_{3}\right), 2.65$ (2H, t, H-1', $J=6.4 \mathrm{~Hz}$ ), 1.92-1.88 (2H, m, H-2') ppm. ${ }^{13} \mathrm{C}-\mathrm{NMR}:(\delta) 168.5$ (C-4), $164.4(\mathrm{C}-2), 159.2(\mathrm{C}-6), 109.2$ $(\mathrm{C}-5), 68.3\left(\mathrm{C}-3^{\prime}\right), 54.7\left(\mathrm{OCH}_{3}\right), 21.0\left(\mathrm{C}-2^{\prime}\right), 21.4\left(\mathrm{C}-1^{\prime}\right)$ ppm. MS (ESI): $m / z=167.1\left([\mathrm{M}+\mathrm{H}]^{+}\right)$.

9: ${ }^{1} \mathrm{H}-\mathrm{NMR}:(\delta) 8.1(1 \mathrm{H}, \mathrm{s}, \mathrm{H}-6), 4.47(1 \mathrm{H}, \mathrm{t}, \mathrm{OH}, J=5.2 \mathrm{~Hz}), 3.92\left(3 \mathrm{H}, \mathrm{s}, \mathrm{OCH}_{3}\right), 3.87(3 \mathrm{H}, \mathrm{s}$, $\left.\mathrm{OCH}_{3}\right), 3.41\left(2 \mathrm{H}, \mathrm{q}, \mathrm{H}-3^{\prime}, J=6.0 \mathrm{~Hz}\right), 2.47\left(2 \mathrm{H}, \mathrm{t}, \mathrm{H}-1^{\prime}, J=7.7 \mathrm{~Hz}\right), 1.65\left(2 \mathrm{H}, \mathrm{k}, \mathrm{H}-2^{\prime}, J=7.0 \mathrm{~Hz}\right)$ ppm. ${ }^{13} \mathrm{C}-\mathrm{NMR}:(\delta) 169.3$ (C-4), 164.0 (C-2), 157.5 (C-6), 115.1 (C-5), 60.5 (C-3'), $54.7\left(\mathrm{OCH}_{3}\right), 54.1$ $\left(\mathrm{OCH}_{3}\right), 32.1\left(\mathrm{C}-2^{\prime}\right), 22.9\left(\mathrm{C}-1^{\prime}\right)$ ppm. MS (ESI): $m / z=199.1\left([M+\mathrm{H}]^{+}\right)$.

5-(3-Acetoxypropyl)-2,4-dimethoxypyrimidine (11). To a stirred solution of compound 9 (5.2 g, $26.23 \mathrm{mmol})$ in dry pyridine $(48 \mathrm{~mL})$ acetic anhydride $(20 \mathrm{~mL}, 26.4 \mathrm{mmol})$ was added and the stirring was continued for $1 \mathrm{~h}$ at room temperature. After the completion of reaction $15 \mathrm{~mL}$ of water was added. The solvent was evaporated and the residue was purified by column chromatography $\left(\mathrm{CH}_{2} \mathrm{Cl}_{2}-\mathrm{CH}_{3} \mathrm{OH}=30: 1\right)$ to yield compound 11 as a yellow oil (6.1 g, 97\%). ${ }^{1} \mathrm{H}-\mathrm{NMR}:(\delta) 8.12(1 \mathrm{H}, \mathrm{s}, \mathrm{H}-6), 3.98$ (2H, t, H-3', $J=6.5 \mathrm{~Hz}), 3.91\left(3 \mathrm{H}, \mathrm{s}, \mathrm{OCH}_{3}\right), 3.86\left(3 \mathrm{H}, \mathrm{s}, \mathrm{OCH}_{3}\right), 2.49(2 \mathrm{H}, \mathrm{t}, \mathrm{H}-1$ ', $J=7.8 \mathrm{~Hz}), 2.0(3 \mathrm{H}, \mathrm{s}$, $\left.\mathrm{COCH}_{3}\right), 1.81\left(2 \mathrm{H}, \mathrm{k}, \mathrm{H}-2{ }^{\prime}, J=7.0 \mathrm{~Hz}\right)$ ppm. ${ }^{13} \mathrm{C}-\mathrm{NMR}:(\delta) 170.85\left(\mathrm{COCH}_{3}\right), 169.29(\mathrm{C}-4), 162.9$ (C-2), 157.7 (C-6), $114.3(\mathrm{C}-5), 63.6(\mathrm{C}-3 '), 54.7\left(\mathrm{OCH}_{3}\right), 54.2\left(\mathrm{OCH}_{3}\right), 27.8\left(\mathrm{C}-2^{\prime}\right), 22.9\left(\mathrm{C}-1^{\prime}\right), 21.1$ $\left(\mathrm{COCH}_{3}\right) \mathrm{ppm}$. MS (ESI): $m / z=241.1\left([M+\mathrm{H}]^{+}\right)$.

5-(3-Acetoxypropyl)-4-methoxypyrimidin-2-one (15). To a dried two-necked flask compound 11 (3.23 g, $13.44 \mathrm{mmol})$ and acetyl chloride $(26 \mathrm{~mL}, 0.36 \mathrm{~mol})$ were added under argon atmosphere. The reaction mixture was stirred at room temperature for $20 \mathrm{~h}$. After the reaction was complete, the solvent was evaporated at reduced pressure at $35{ }^{\circ} \mathrm{C}$ and coevaporated twice by the addition of toluene $(6 \mathrm{~mL})$. The residue was chromatographed $\left(\right.$ EtOAc- $\left.-\mathrm{CH}_{3} \mathrm{OH}=20: 1\right)$. During this step, the intermediate 13 was deacetylated to form a white crystalline product 15 (1.79 g, 59\%, m.p.: 146-149 $\left.{ }^{\circ} \mathrm{C}\right)$. Compound 4 was also isolated (966 mg, 34\%). ${ }^{1} \mathrm{H}-\mathrm{NMR}:(\delta) 11.14(1 \mathrm{H}, \mathrm{s}, \mathrm{NH}), 7.50(1 \mathrm{H}, \mathrm{s}, \mathrm{H}-6), 3.97$ (2H, t, H-3', $J=6.5 \mathrm{~Hz}), 3.83\left(3 \mathrm{H}, \mathrm{s}, \mathrm{OCH}_{3}\right), 2.32\left(2 \mathrm{H}, \mathrm{t}, \mathrm{H}-1^{\prime}, J=7.4 \mathrm{~Hz}\right), 1.99\left(3 \mathrm{H}, \mathrm{s}, \mathrm{COCH}_{3}\right), 1.75\left(2 \mathrm{H}, \mathrm{k}, \mathrm{H}-2^{\prime}\right.$, $J=6.7 \mathrm{~Hz})$ ppm. ${ }^{13} \mathrm{C}-\mathrm{NMR}:(\delta) 170.9\left(\mathrm{COCH}_{3}\right), 170.8(\mathrm{C}-4), 156.6(\mathrm{C}-2), 143.1(\mathrm{C}-6), 105.8(\mathrm{C}-5)$, $63.6\left(\mathrm{C}^{-} 3^{\prime}\right), 54.1\left(\mathrm{OCH}_{3}\right), 27.8\left(\mathrm{C}-2^{\prime}\right), 22.8\left(\mathrm{C}-1^{\prime}\right), 21.1\left(\mathrm{COCH}_{3}\right) \mathrm{ppm}$. MS (ESI): $m / z=227.2\left([M+\mathrm{H}]^{+}\right)$.

5-(2-Acetoxyethyl)-N-1-allyl-4-methoxypyrimidin-2-one (17). Method A: A solution of compound 10 (375 mg, $1.66 \mathrm{mmol})$ and allyl bromide $(0.15 \mathrm{~mL}, 1.73 \mathrm{mmol})$ was heated under reflux for $8 \mathrm{~h}$. After evaporation of the solvent and column chromatography (ethyl acetate: $\mathrm{CH}_{3} \mathrm{OH}=15: 1$ ) compound 17 was obtained as a colourless oil (305.3 mg, 73\%). ${ }^{1} \mathrm{H}-\mathrm{NMR}:(\delta) 7.78(1 \mathrm{H}, \mathrm{s}, \mathrm{H}-6), 5.90(1 \mathrm{H}, \mathrm{m}$, H-2"), $5.16\left(1 \mathrm{H}, \mathrm{dd}, \mathrm{H}-3 ", J_{1}=1.3 \mathrm{~Hz}, J_{2}=10.3 \mathrm{~Hz}\right), 5.06\left(1 \mathrm{H}, \mathrm{dd}, \mathrm{H}-3 ", J_{1}=1.4 \mathrm{~Hz}, J_{2}=17.2 \mathrm{~Hz}\right)$, $4.08\left(2 \mathrm{H}, \mathrm{t}, \mathrm{H}-2^{\prime}, J=6.6 \mathrm{~Hz}\right), 4.36(2 \mathrm{H}, \mathrm{d}, \mathrm{H}-1$ ", $J=5.4 \mathrm{~Hz}), 3.83\left(3 \mathrm{H}, \mathrm{s}, \mathrm{OCH}_{3}\right), 2.57$ (2H, t, H-1', $J=6.5 \mathrm{~Hz}), 1.95\left(3 \mathrm{H}, \mathrm{s}, \mathrm{COCH}_{3}\right)$ ppm. ${ }^{13} \mathrm{C}-\mathrm{NMR}:(\delta) 170.7\left(\mathrm{COCH}_{3}\right), 170.1(\mathrm{C}-4), 155.6(\mathrm{C}-2), 147.5$ (C-6), 103.6 (C-5), 133.7 (C-2"), 117.8 (C-3"), 62.6 (C-2'), $54.5\left(\mathrm{OCH}_{3}\right), 51.1(\mathrm{C}-1 "), 26.0\left(\mathrm{C}-1{ }^{\prime}\right), 21.1$ $\left(\mathrm{COCH}_{3}\right) \mathrm{ppm}$. MS (ESI): $m / z=253.1\left([M+\mathrm{H}]^{+}\right)$. 
5-(2-Acetoxyethyl)-N-1-(2,3-dihydroxypropyl)-4-methoxypyrimidin-2-one (18). Method A: $\mathrm{OsO}_{4}(1 \mathrm{mg}$, $0.004 \mathrm{mmol})$ was added to a solution of compound $17(203.5 \mathrm{mg}, 0.81 \mathrm{mmol})$, followed by addition of sodium chlorate $(103 \mathrm{mg}, 0.97 \mathrm{mmol})$ dissolved in water $(2.5 \mathrm{~mL})$. The reaction mixture was stirred at room temperature for 3 days. The mixture was then filtered through Celite and applied to an Amberlite IR 4 B column using water as eluens. The product was evaporated to dryness and applied on a Dowex (100-200 mesh, $\mathrm{H}^{+}$-form) column and eluted with water. The eluate was evaporated under reduced pressure and the residue was purified by column chromatography $\left(\mathrm{CH}_{2} \mathrm{Cl}_{2}-\mathrm{CH}_{3} \mathrm{OH}=10: 1\right)$ to yield compound 18 as a yellow oil (115.5 mg, 50\%). ${ }^{1} \mathrm{H}-\mathrm{NMR}:(\delta) 7.71(1 \mathrm{H}, \mathrm{s}, \mathrm{H}-6), 4.95(1 \mathrm{H}, \mathrm{d}, \mathrm{OH}$, $J=5.5 \mathrm{~Hz}), 4.95(1 \mathrm{H}, \mathrm{t}, \mathrm{OH}, J=5.4 \mathrm{~Hz}), 4.02-4.11\left(3 \mathrm{H}, \mathrm{m}, \mathrm{H}-2^{\prime}, \mathrm{H}-3 "\right), 3.84\left(3 \mathrm{H}, \mathrm{s}, \mathrm{OCH}_{3}\right)$, 3.70-3.78 (1H, m, H-2"), 3.42-3.48 (1H, m, H-3"), covered with water (H-1"), 2.58 (2H, t, H-1', $J=6.5 \mathrm{~Hz}), 1.98\left(3 \mathrm{H}, \mathrm{s}, \mathrm{COCH}_{3}\right)$ ppm. ${ }^{13} \mathrm{C}-\mathrm{NMR}:(\delta) 170.8\left(\mathrm{COCH}_{3}\right), 170.0(\mathrm{C}-4), 156.0(\mathrm{C}-2), 149.2$ (C-6), 102.4 (C-5), 69.2 (C-2"), 64.1 (C-3"), 62.6 (C-2'), $54.4\left(\mathrm{OCH}_{3}\right), 53.0\left(\mathrm{C}-1^{\prime \prime}\right), 25.9$ (C-1'), 21.1 $\left(\mathrm{COCH}_{3}\right)$ ppm. MS (ESI): $m / z=287.1\left([M+\mathrm{H}]^{+}\right)$.

5-(2-Hydroxyethyl)-N-1-(2,3-dihydroxypropyl)pyrimidin-2,4-dione (19). Method A: Compound 18 $(92.4 \mathrm{mg}, 0.32 \mathrm{mmol})$ was dissolved in $1 \mathrm{M} \mathrm{NaOH}(8 \mathrm{~mL})$ and the mixture was stirred at room temperature for $20 \mathrm{~h}$. Then, it was neutralized by the addition of acetic acid. After evaporation of the solvents and column chromatography $\left(\mathrm{CH}_{2} \mathrm{Cl}_{2}-\mathrm{CH}_{3} \mathrm{OH}=5: 1\right)$ white crystals of compound 19 were obtained (29 mg, 39\%, m.p.: 95-98 $\left.{ }^{\circ} \mathrm{C}\right)$.

Method B: Compound $24(164 \mathrm{mg}, 0.67 \mathrm{mmol})$ was dissolved in $1 \mathrm{M} \mathrm{NaOH}(20 \mathrm{~mL})$ and the mixture was stirred at room temperature for $20 \mathrm{~h}$ and neutralized by the addition of $\mathrm{HCl}$. After evaporation of the solvent and column chromatography $\left(\mathrm{CH}_{2} \mathrm{Cl}_{2}-\mathrm{CH}_{3} \mathrm{OH}=5: 1\right)$, compound 19 was obtained (57.7 mg, 37\%). ${ }^{1} \mathrm{H}-\mathrm{NMR}:(\delta) 11.18(1 \mathrm{H}, \mathrm{bs}, \mathrm{NH}), 7.36(1 \mathrm{H}, \mathrm{s}, \mathrm{H}-6), 4.95(1 \mathrm{H}, \mathrm{d}, \mathrm{OH}$, $J=5.5 \mathrm{~Hz}), 4.69(1 \mathrm{H}, \mathrm{t}, \mathrm{OH}, J=5.6 \mathrm{~Hz}), 4.53(1 \mathrm{H}, \mathrm{t}, \mathrm{OH}, J=5.6 \mathrm{~Hz}), 3.89\left(1 \mathrm{H}, \mathrm{dd}, \mathrm{H}-3 ", J_{l}=3.8 \mathrm{~Hz}\right.$, $J_{2}=13.3 \mathrm{~Hz}$ ), 3.64-3.72 (1H, m, H-2"), 3.45 (2H, q, H-2', J=6.7 Hz), 3.36-3.41 (3H, m, H-3", H-1"), 2.29-2.34 (2H, m, H-1') ppm. ${ }^{13} \mathrm{C}-\mathrm{NMR}:(\delta) 164.6$ (C-4), 151.5 (C-2), 144.3 (C-6), 109.3 (C-5), 69.6 (C-2"), 64.1 (C-3"), 60.0 (C-2'), 51.4 (C-1"), 30.4 (C-1') ppm. MS (ESI): $m / z=231.1\left([M+\mathrm{H}]^{+}\right)$. Anal. Calcd for $\mathrm{C}_{9} \mathrm{H}_{14} \mathrm{~N}_{2} \mathrm{O}_{5}$ : C, 46.95; H, 6.13; N, 12.17. Found: C, 46.90; H, 6.15; N, 12.22.

N-1-[(2-Acetoxyethoxy)methyl]-5-(2-acetoxyethyl)pyrimidin-2,4-dione (20). Method A: To a stirred solution of compound $10(47.2 \mathrm{mg}, 0.21 \mathrm{mmol})$ and $\mathrm{Na}_{2} \mathrm{CO}_{3}(21.9 \mathrm{mg}, 0.2 \mathrm{mmol})$ in anhydrous $\mathrm{CH}_{2} \mathrm{Cl}_{2}$ (1 mL), (2-acethoxyethoxy)methyl bromide [prepared in situ by adding acetyl bromide $(0.02 \mathrm{~mL}$, $0.2 \mathrm{mmol})$ to 1,3 -dioxolane $(0.01 \mathrm{~mL}, 0.2 \mathrm{mmol})]$ was added. The reaction mixture was stirred overnight at room temperature and evaporated to dryness. After column chromatography $\left(\mathrm{CH}_{2} \mathrm{Cl}_{2}-\mathrm{CH}_{3} \mathrm{OH}=20: 1\right)$ compound 20 was isolated as a crude product $\left(28.2 \mathrm{mg}, 43 \%\right.$, m.p.: $\left.53-55^{\circ} \mathrm{C}\right) .{ }^{1} \mathrm{H}-\mathrm{NMR}:(\delta) 11.41(1 \mathrm{H}$, bs, NH), 7.64 (1H, s, H-6), 5.09 (2H, s, H-1"), 4.06-4.17 (4H, m, H-3", H-4"), 3.69 (2H, t, H-2', $J=4.6 \mathrm{~Hz}), 2.70\left(2 \mathrm{H}, \mathrm{t}, \mathrm{H}-1^{\prime}, J=6.4 \mathrm{~Hz}\right), 1.99\left(3 \mathrm{H}, \mathrm{s}, \mathrm{COCH}_{3}\right), 1.98\left(3 \mathrm{H}, \mathrm{s}, \mathrm{COCH}_{3}\right) \mathrm{ppm} .{ }^{13} \mathrm{C}-\mathrm{NMR}:$ (d) $170.2\left(\underline{\mathrm{COCH}}_{3}\right), 163.7$ (C-4), 150.9 (C-2), 142.0 (C-6), 109.4 (C-5), 76.3 (C-1"), 66.7 (C-3"), 62.9 (C-4"), 61.9 (C-2'), $25.8\left(\mathrm{C}-1^{\prime}\right), 20.6\left(\mathrm{COC}_{3}\right), 20.6\left(\mathrm{COCH}_{3}\right)$ ppm. MS (ESI): $m / z=315.1\left([\mathrm{M}+\mathrm{H}]^{+}\right)$.

N-1-[(2-Hydroxyethoxy)methyl]-5-(2-hydroxyethyl)pyrimidin-2,4-dione (21). Method A: To a solution of sodium $(2.1 \mathrm{mg}, 0.09 \mathrm{mmol})$ in anhydrous methanol $(0.5 \mathrm{~mL})$ compound 20 (27 $\mathrm{mg}, 0.09 \mathrm{mmol})$ 
dissolved in methanol $(1 \mathrm{~mL})$ was added. The reaction mixture was stirred at room temperature for $1 \mathrm{~h}$ and neutralized with $1 \mathrm{M} \mathrm{HCl} /$ ether. After evaporation to dryness and column chromatography $\left(\mathrm{CH}_{2} \mathrm{Cl}_{2}-\mathrm{CH}_{3} \mathrm{OH}=5: 1\right)$ compound 21 was isolated $(14.6 \mathrm{mg}, 74 \%)$ as a colourless oil.

Method B: Compound 25 (37 mg, $0.15 \mathrm{mmol})$ was dissolved in $1 \mathrm{M} \mathrm{NaOH}(10 \mathrm{~mL})$ and the mixture was stirred at room temperature for $20 \mathrm{~h}$. Then, it was neutralized by the addition of acetic acid. After evaporation of the solvents and column chromatography (ethyl acetate- $\mathrm{CH}_{3} \mathrm{OH}=5: 1$ ) compound 21 was obtained (9.1 mg, 26\%). ${ }^{1} \mathrm{H}-\mathrm{NMR}$ : $(\delta) 11.25(1 \mathrm{H}, \mathrm{bs}, \mathrm{NH}), 7.52(1 \mathrm{H}, \mathrm{s}, \mathrm{H}-6), 5.08$ (2H, s, H-1"), 4.60 (2H, bs, OH), 3.45-3.50 (6H, m, H-2', H-3", H-4"), 2.35 (2H, t, H-1', J=6.6 Hz) ppm. ${ }^{13} \mathrm{C}-\mathrm{NMR}$ :

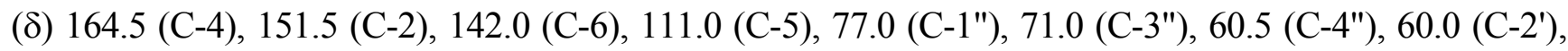
$30.3\left(\mathrm{C}-1^{\prime}\right)$ ppm. MS (ESI): $m / z=231.1\left([M+\mathrm{H}]^{+}\right)$. Anal. Calcd for $\mathrm{C}_{9} \mathrm{H}_{14} \mathrm{~N}_{2} \mathrm{O}_{5}: \mathrm{C}, 46.95 ; \mathrm{H}, 6.13 ; \mathrm{N}$, 12.17. Found: C, 46.99; H, 6.15; N, 12.12 .

5-(2-Acetoxyethyl)-N-1-[(1,3-dibenzyloxy-2-propoxy)methyl]pyrimidin-2,4-dione (22). Method A: To a stirred solution of compound $10(114 \mathrm{mg}, 0.50 \mathrm{mmol})$ and $\mathrm{K}_{2} \mathrm{CO}_{3}(186.4 \mathrm{mg}, 1.35 \mathrm{mmol})$ in anhydrous $\mathrm{CH}_{2} \mathrm{Cl}_{2}(3.7 \mathrm{~mL})$, 1,3-dibenzyloxy-2-chloromethoxypropane (257.6 mg, $0.8 \mathrm{mmol}$ ) was added under argon atmosphere. The reaction mixture was stirred overnight at room temperature and after filtration evaporated to dryness. After column chromatography $\left(\mathrm{CH}_{2} \mathrm{Cl}_{2}-\mathrm{CH}_{3} \mathrm{OH}=35: 1\right)$ compound 22 was isolated as a colourless oil (87 mg, 36\%). ${ }^{1} \mathrm{H}-\mathrm{NMR}:(\delta) 11.38(1 \mathrm{H}, \mathrm{s}, \mathrm{NH}), 7.63(1 \mathrm{H}, \mathrm{s}, \mathrm{H}-6), 7.40-7.22$ $(10 \mathrm{H}, \mathrm{m}, \mathrm{Ph}), 5.2$ (2H, s, H-1"), 4.46 (4H, s, H-5"), 4.03 (2H, t, H-2', J=6.8 Hz), 3.99-3.94 (1H, m, H-3"), 3.57-3.40 (4H, m, H-4"), 2.44 (2H, t, H-1', $J=6.8 \mathrm{~Hz}), 1.98\left(3 \mathrm{H}, \mathrm{s}, \mathrm{COCH}_{3}\right)$ ppm. ${ }^{13} \mathrm{C}-\mathrm{NMR}:$

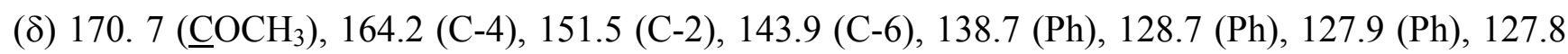
(Ph), 109.7 (C-5), 77.2 (C-3"), 76.5 (C-1"), 72.7 (C-5"), 70.3 (C-4"), 62.4 (C-2'), 26.2 (C-1'), 21.1 $\left(\mathrm{COCH}_{3}\right) \mathrm{ppm}$. MS (ESI): $m / z=483.2\left([M+\mathrm{H}]^{+}\right)$.

5-(2-Hydroxyethyl)-N-1-[(1,3-dihydroxy-2-propoxy)methyl]pyrimidin-2,4-dione (23). Method A: A solution of compound $22(63 \mathrm{mg}, 0.13 \mathrm{mmol})$ in anhydrous $\mathrm{CH}_{2} \mathrm{Cl}_{2}(5 \mathrm{~mL})$ was cooled to $-68{ }^{\circ} \mathrm{C}$ and $1 \mathrm{M}$ solution of $\mathrm{BCl}_{3}$ in $\mathrm{CH}_{2} \mathrm{Cl}_{2}(0.45 \mathrm{~mL}, 0.45 \mathrm{mmol})$ was added under argon atmosphere. The reaction mixture was stirred at $-68{ }^{\circ} \mathrm{C}$ for $3 \mathrm{~h}$, quenched by the addition of $\mathrm{CH}_{2} \mathrm{Cl}_{2}-\mathrm{CH}_{3} \mathrm{OH}(1: 1)$ solution $(15 \mathrm{~mL})$ and allowed to warm to room temperature. The solvent was then evaporated and the residue chromatographed $\left(\mathrm{CH}_{2} \mathrm{Cl}_{2}-\mathrm{CH}_{3} \mathrm{OH}=25: 1\right)$. Compound 23 was isolated as a white solid $(22.7 \mathrm{mg}$, $67 \%$, m.p.: $\left.118-120{ }^{\circ} \mathrm{C}\right)$.

Method B: In the same way as described for 22, the deprotection of $\mathbf{2 6}$ was performed. The reagents used were: compound 26 (106 mg, $0.24 \mathrm{mmol})$, anhydrous $\mathrm{CH}_{2} \mathrm{Cl}_{2}(5 \mathrm{~mL})$ and $\mathrm{BCl}_{3}(0.7 \mathrm{~mL}, 0.7 \mathrm{mmol})$. After column chromatography $\left(\mathrm{CH}_{2} \mathrm{Cl}_{2}-\mathrm{CH}_{3} \mathrm{OH}=10: 1\right)$ compound 23 (40.9 $\left.\mathrm{mg}, 65 \%\right)$ was isolated. ${ }^{1} \mathrm{H}-\mathrm{NMR}:(\delta) 11.27(1 \mathrm{H}, \mathrm{s}, \mathrm{NH}), 7.53(1 \mathrm{H}, \mathrm{s}, \mathrm{H}-6), 5.16(2 \mathrm{H}, \mathrm{s}, \mathrm{H}-1 "), 4.64-4.59(3 \mathrm{H}, \mathrm{m}, 3 \times \mathrm{OH})$, 3.52-3.40 (7H, m, H-2', H-4", H-3") 2.35 (2H, t, H-1', J=6.6 Hz) ppm. ${ }^{13} \mathrm{C}-\mathrm{NMR}:(\delta) 164.5$ (C-4), 151.4 (C-2), 142.1 (C-6), 110.7 (C-5), 80.9 (C-3"), 76.3 (C-1"), 61.4 (C-4"), 59.9 (C-2'), 30.3 (C-1') ppm. MS (ESI): $m / z=261.1\left([M+\mathrm{H}]^{+}\right)$. Anal. Calcd for $\mathrm{C}_{10} \mathrm{H}_{16} \mathrm{~N}_{2} \mathrm{O}_{6}: \mathrm{C}, 46.15 ; \mathrm{H}, 6.20 ; \mathrm{N}, 10.76$. Found: C, 46.10; H, 6.22; N, 10.72 .

5-(2-Hydroxyethyl)-N-1-(2,3-dihydroxypropyl)-4-methoxypyrimidin-2-one (24). Method B: A mixture of compound 14 (194.4 mg, $0.91 \mathrm{mmol}$ ) and sodium hydride (90.9 mg, $2.27 \mathrm{mmol}, 60 \%$ dispersion in 
oil) in DMF $(6 \mathrm{~mL})$ was stirred at $60{ }^{\circ} \mathrm{C}$ for $1 \mathrm{~h}$. To the resulting suspension glycerol $\alpha$-chlorohydrine $(0.6 \mathrm{~mL}, 6.82 \mathrm{mmol})$ was added dropwise and the mixture was stirred at $70{ }^{\circ} \mathrm{C}$ overnight. The solvent was evaporated under reduced pressure and after column chromatography $\left(\mathrm{CH}_{2} \mathrm{Cl}_{2}-\mathrm{CH}_{3} \mathrm{OH}=5: 1\right)$ compound 24 (166.9 mg, 75\%) was obtained. ${ }^{1} \mathrm{H}-\mathrm{NMR}:(\delta) 7.63(1 \mathrm{H}, \mathrm{s}, \mathrm{H}-6), 4.92(1 \mathrm{H}, \mathrm{d}, \mathrm{OH}$, $J=5.8 \mathrm{~Hz}), 4.71(1 \mathrm{H}, \mathrm{t}, \mathrm{OH}, J=5.8 \mathrm{~Hz}), 4.53(1 \mathrm{H}, \mathrm{t}, \mathrm{OH}, J=5.5 \mathrm{~Hz}), 4.05\left(1 \mathrm{H}, \mathrm{dd}, \mathrm{H}-3 ", J_{l}=3.3 \mathrm{~Hz}\right.$, $\left.J_{2}=13.0 \mathrm{~Hz}\right), 3.83\left(3 \mathrm{H}, \mathrm{s}, \mathrm{OCH}_{3}\right), 3.69-3.71(1 \mathrm{H}, \mathrm{m}, \mathrm{H}-2 "), 3.5-3.4(2 \mathrm{H}, \mathrm{m}, \mathrm{H}-2$ '), covered with water (H-3", H-1"), 2.40 (2H, t, H-1', $J=6.4 \mathrm{~Hz}$ ) ppm. ${ }^{13} \mathrm{C}-\mathrm{NMR}:(\delta) 170.2$ (C-4), 156.9 (C-2), 148.8 (C-6), 103.6 (C-5), 69.3 (C-2"), 64.1 (C-3"), 60.1 (C-2'), $54.3\left(\mathrm{OCH}_{3}\right), 53.0(\mathrm{C}-1 "), 30.0$ (C-1') ppm. MS (ESI): $m / z=245.1\left([M+\mathrm{H}]^{+}\right)$.

N-1-[(2-Hydroxyethoxy)methyl]-5-(2-hydroxyethyl)-4-methoxypyrimidin-2-one (25). Method B: To a stirred solution of compound $16(110 \mathrm{mg}, 0.65 \mathrm{mmol})$ in acetonitrile $(6 \mathrm{~mL})$ under exclusion of moisture $\mathrm{N}, \mathrm{O}$-bis-trimethysilylacetamide (BSA: $0.8 \mathrm{~mL}, 3.2 \mathrm{mmol}$ ) was added. The mixture was stirred until a clear solution appeared (about $10 \mathrm{~min})$. Dioxolane $(0.12 \mathrm{~mL}, 1.66 \mathrm{mmol}), \mathrm{KI}(139 \mathrm{mg}$, $0.83 \mathrm{mmol})$ and TMSCl $(0.1 \mathrm{~mL})$ were added sequentially. The stirring was continued for $48 \mathrm{~h}$ at room temperature. The volatile materials were evaporated under reduced pressure and the residue was purified using column chromatography $\left(\mathrm{CH}_{2} \mathrm{Cl}_{2}-\mathrm{CH}_{3} \mathrm{OH}=5: 1\right)$ to give compound $25(39.1 \mathrm{mg}, 25 \%)$. ${ }^{1} \mathrm{H}-\mathrm{NMR}:(\delta) 7.78$ (1H, s, H-6), 5.17 (2H, s, H-1"), $4.62(1 \mathrm{H}, \mathrm{t}, \mathrm{OH}, J=5.4 \mathrm{~Hz}), 4.59$ (1H, t, OH, $J=5.4 \mathrm{~Hz}), 3.45-3.56$ (4H, m, H-3", H-4"), $3.84\left(3 \mathrm{H}, \mathrm{s}, \mathrm{OCH}_{3}\right), 3.62$ (2H, t, H-2', $\left.J=6.4 \mathrm{~Hz}\right), 2.45$ $(2 \mathrm{H}, \mathrm{t}, \mathrm{H}-1$ ', $J=6.6 \mathrm{~Hz})$ ppm. ${ }^{13} \mathrm{C}-\mathrm{NMR}:(\delta) 171.7(\mathrm{C}-4), 155.8(\mathrm{C}-2), 146.8(\mathrm{C}-6), 105.1(\mathrm{C}-5), 78.3$ (C-1"), 71.3 (C-3"), 60.5 (C-4"), 59.8 (C-2'), $54.7\left(\mathrm{OCH}_{3}\right), 29.9$ (C-1') ppm. MS (ESI): m/z = 245.1 $\left([M+\mathrm{H}]^{+}\right)$.

5-(2-Hydroxyethyl)-N-1-[(1,3-dibenzyloxy-2-propoxy)methyl]pyrimidin-2,4-dione (26) and 5-(2chloroethyl)-N-1-[(1,3-dibenzyloxy-2-propoxy)methyl]pyrimidin-2,4-dione (27). Method B: A mixture of compound 1 (1.3 g, $8.33 \mathrm{mmol})$, hexamethyldisilazane $(30 \mathrm{~mL})$, trimethylsilyl chloride $(0.58 \mathrm{~mL}$, $4.57 \mathrm{mmol})$ and $\left(\mathrm{NH}_{4}\right)_{2} \mathrm{SO}_{4}(416 \mathrm{mg}, 3.15 \mathrm{mmol})$ was refluxed for $24 \mathrm{~h}$ under argon atmosphere. The resultant solution was evaporated in vacuum using oil pump. To the residual oil in acetonitrile $(50 \mathrm{~mL})$, TBAI (73.7 mg, $0.2 \mathrm{mmol}$ ) and 1,3-dibenzyloxy-2-chloromethoxypropane (4 g, $12.45 \mathrm{mmol}$ ) were added under argon atmosphere. The reaction mixture was stirred at reflux overnight. After the reaction was complete the solvent was evaporated and the residue purified using column chromatography $\left(\mathrm{CH}_{2} \mathrm{Cl}_{2}-\mathrm{CH}_{3} \mathrm{OH}=35: 1\right)$ to obtain compounds 26 (289.6 mg, 8\%) and 27 (87.3 $\left.\mathrm{mg}, 2 \%\right)$.

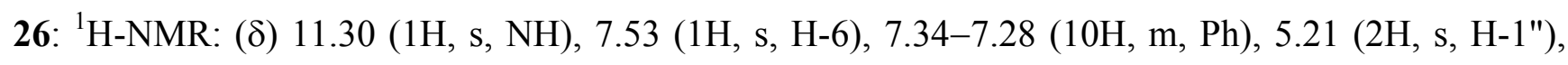
4.56 (1H, t, OH, $J=5.4 \mathrm{~Hz}$ ), 4.46 (4H, s, H-5"), 4.0-3.9 (1H, m, H-3") 3.50-3.40 (6H, m, H-2', H-4"), $2.30\left(2 \mathrm{H}, \mathrm{t}, \mathrm{H}-1^{\prime}, J=6.7 \mathrm{~Hz}\right)$ ppm. ${ }^{13} \mathrm{C}-\mathrm{NMR}:(\delta) 164.4(\mathrm{C}-4), 151.6$ (C-2), 142.1 (C-6), 138.7 (C-Ph), 128.7 (C-Ph), 127.8 (C-Ph), 127.8 (C-Ph), 111.0 (C-5), 77.1 (C-3"), 76.5 (C-1"), 72.7 (C-5"), 70.3 (C-4"), $60.0\left(\mathrm{C}-2^{\prime}\right), 30.3\left(\mathrm{C}-1^{\prime}\right)$ ppm. MS (ESI): $m / z=441.3\left([M+\mathrm{H}]^{+}\right)$.

27: ${ }^{1} \mathrm{H}-\mathrm{NMR}:(\delta) 11.43$ (1H, s, NH), 7.69 (1H, s, H-6), 7.38-7.2 (10H, m, Ph), 5.20 (2H, s, H-1"), 4.46 (4H, s, H-5"), 4.04-3.95 (1H, m, H-3"), 3.62 (2H, t, H-2', J=6.9 Hz), 3.55-3.40 (4H, m, H-4"), 2.58 (2H, t, H-1', $J=7.0 \mathrm{~Hz}$ ) ppm. ${ }^{13} \mathrm{C}-\mathrm{NMR}:(\delta) 164.1$ (C-4), 151.5 (C-2), 143.0 (C-6), 138.7 (C-Ph), 
128.7 (C-Ph), 127.8 (C-Ph), 127.7 (C-Ph), 109.8 (C-5), 77.2 (C-3"), 76.6 (C-1"), 72.7 (C-5"), 70.3 (C-4"), 43.5 (C-2'), $30.2\left(\mathrm{C}-1^{\prime}\right)$ ppm. MS (ESI): $m / z=459.2\left([M+\mathrm{H}]^{+}\right)$.

5-(2-Chloroethyl)-N-1-[(1,3-dihydroxy-2-propoxy)methyl]pyrimidin-2,4-dione (28). Method B: In the similar way as described for compound $\mathbf{2 3}$, the synthesis of $\mathbf{2 8}$ was performed. The reagents used were: compound $27(43.7 \mathrm{mg}, 0.1 \mathrm{mmol})$, anhydrous $\mathrm{CH}_{2} \mathrm{Cl}_{2}(8 \mathrm{~mL})$ and $\mathrm{BCl}_{3}(0.7 \mathrm{~mL}, 0.7 \mathrm{mmol})$. After column chromatography $\left(\mathrm{CH}_{2} \mathrm{Cl}_{2}-\mathrm{CH}_{3} \mathrm{OH}=5: 1\right)$ compound $28(15 \mathrm{mg}, 57 \%)$ was isolated. ${ }^{1} \mathrm{H}-\mathrm{NMR}:(\delta) 11.36(1 \mathrm{H}, \mathrm{s}, \mathrm{NH}), 7.65(1 \mathrm{H}, \mathrm{s}, \mathrm{H}-6), 5.13(2 \mathrm{H}, \mathrm{s}, \mathrm{H}-1 "), 4.58(2 \mathrm{H}, \mathrm{t}, 2 \times \mathrm{OH}, J=5.5 \mathrm{~Hz})$, $3.66\left(2 \mathrm{H}, \mathrm{t}, \mathrm{H}-2^{\prime}, J=6.9 \mathrm{~Hz}\right), 3.51-3.32$ (5H, m, H-3", H-4"), $2.62(2 \mathrm{H}, \mathrm{t}, \mathrm{H}-1$ ', $J=6.9 \mathrm{~Hz}) \mathrm{ppm}$.

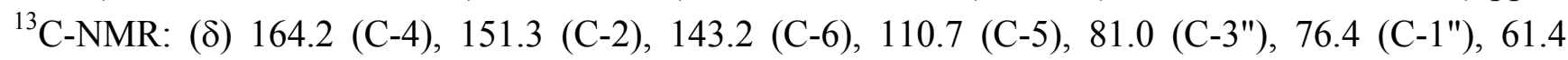
$(\mathrm{C}-4 "), 43.6\left(\mathrm{C}-2^{\prime}\right), 30.3\left(\mathrm{C}-1^{\prime}\right) \mathrm{ppm}$. MS (ESI): $m / z=279.2\left([M+\mathrm{H}]^{+}\right)$.

N-1-[4-Acetoxy-(3-acetoxymethyl)butyl]-5-(2-acetoxyethyl)-4-methoxypyrimidin-2-one (29). To a stirred solution of compound $14(76.3 \mathrm{mg}, 0.36 \mathrm{mmol})$ and $\mathrm{K}_{2} \mathrm{CO}_{3}(74.5 \mathrm{mg}, 0.54 \mathrm{mmol})$ in anhydrous DMF (7.6 mL), 4-acetoxy-(3-acetoxymethyl)butyl iodide (192 mg, $0.61 \mathrm{mmol})$ was added under argon atmosphere. The reaction mixture was stirred at $60{ }^{\circ} \mathrm{C}$ for $20 \mathrm{~min}$ and then evaporated to dryness. After column chromatography $\left(\mathrm{CH}_{2} \mathrm{Cl}_{2}-\mathrm{CH}_{3} \mathrm{OH}=30: 1\right)$ compound 29 was isolated as a colourless oil

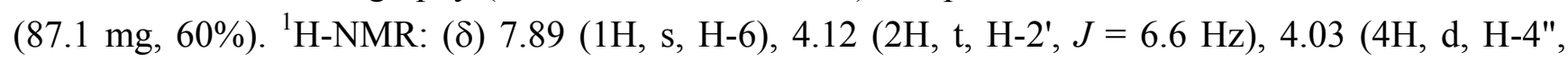
$J=5.8 \mathrm{~Hz}), 3.85\left(3 \mathrm{H}, \mathrm{s}, \mathrm{OCH}_{3}\right), 3.83(2 \mathrm{H}, \mathrm{t}, \mathrm{H}-1$ ", $J=7.7 \mathrm{~Hz}), 2.60(2 \mathrm{H}, \mathrm{t}, \mathrm{H}-1$ ', $J=6.6 \mathrm{~Hz}), 2.02$ $\left(6 \mathrm{H}, \mathrm{s}, 2 \times \mathrm{COCH}_{3}\right), 1.99\left(3 \mathrm{H}, \mathrm{s}, \mathrm{COCH}_{3}\right)$, within $\mathrm{COCH}_{3}$ signal $(\mathrm{H}-3 ") 1.67(2 \mathrm{H}, \mathrm{q}, \mathrm{H}-2 ", J=7.1 \mathrm{~Hz})$ ppm. ${ }^{13} \mathrm{C}-\mathrm{NMR}:(\delta) 170.8\left(\mathrm{COCH}_{3}\right), 169.9$ (C-4), 155.6 (C-2), 147.7 (C-6), 103.3 (C-5), 64.0 (C-4"), $62.6\left(\mathrm{C}-2^{\prime}\right), 54.3\left(\mathrm{OCH}_{3}\right), 47.2\left(\mathrm{C}-1^{\prime \prime}\right), 34.9$ (C-3"), 27.9 (C-1') 26.0 (C-2"), $21.1\left(\mathrm{COCH}_{3}\right)$ ppm. MS (ESI): $m / z=399.2\left([M+\mathrm{H}]^{+}\right)$.

N-1-[4-Acetoxy-(3-acetoxymethyl)butyl]-5-(3-acetoxypropyl)-4-methoxypyrimidin-2-one (30). The synthesis of $\mathbf{3 0}$ was performed as described for 29. The reagents used were: compound $\mathbf{1 5}(1.54 \mathrm{~g}$, $6.81 \mathrm{mmol}), \mathrm{K}_{2} \mathrm{CO}_{3}(1.41 \mathrm{~g}, 10.2 \mathrm{mmol})$, anhydrous DMF (40 mL) and 4-acetoxy-(3acetoxymethyl)butyl iodide $(3.63 \mathrm{~g}, 11.6 \mathrm{mmol})$. After column chromatography $\left(\mathrm{CH}_{2} \mathrm{Cl}_{2}-\mathrm{CH}_{3} \mathrm{OH}=\right.$ 50:1) compound 30 was isolated as a yellow oil (1.15 g, 41\%). ${ }^{1} \mathrm{H}-\mathrm{NMR}:(\delta) 7.83(1 \mathrm{H}, \mathrm{s}, \mathrm{H}-6)$, 4.04-3.98 (6H, m, H-4", H-3'), 3.84-3.80 (5H, m, $\left.\mathrm{OCH}_{3}, \mathrm{H}-1 "\right), 2.34$ (2H, t, H-1', J= $7.5 \mathrm{~Hz}$ ), 2.02 $\left(6 \mathrm{H}, \mathrm{s}, 2 \times \mathrm{COCH}_{3}\right), 2.00\left(3 \mathrm{H}, \mathrm{s}, \mathrm{COCH}_{3}\right)$, within $\mathrm{COCH}_{3}$ signal $(\mathrm{H}-3 "), 1.78\left(2 \mathrm{H}, \mathrm{k}, \mathrm{H}-2^{\prime}, J=7.0 \mathrm{~Hz}\right)$,

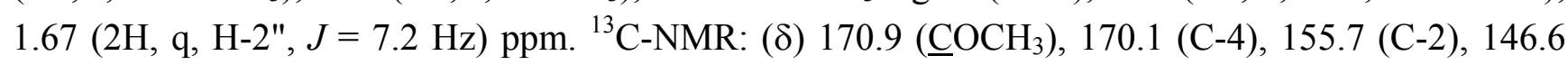
(C-6), 106.5 (C-5), 64.1 (C-4"), 63.6 (C-3'), $54.4\left(\mathrm{OCH}_{3}\right), 47.2$ (C-1"), 34.9 (C-3"), 27.9 (C-2'), 27.7 $(\mathrm{C}-2 "), 22.9\left(\mathrm{C}-1^{\prime}\right), 21.1\left(\mathrm{COCH}_{3}\right), 21.1\left(\mathrm{COCH}_{3}\right) \mathrm{ppm}$. MS (ESI): $m / z=413.2\left([\mathrm{M+H}]^{+}\right)$.

5-(2-Hydroxyethyl)-N-1-[4-hydroxy-(3-hydroxymethyl)butyl]pyrimidin-2,4-dione (31). The synthesis of 31 was performed as described for 19. The reagents used were: compound 29 (62.4 $\mathrm{mg}, 0.16 \mathrm{mmol})$ and $1 \mathrm{M} \mathrm{NaOH}(5 \mathrm{~mL})$. After column chromatography $\left(\mathrm{CH}_{2} \mathrm{Cl}_{2}-\mathrm{CH}_{3} \mathrm{OH}=5: 1\right)$ compound 31 was obtained as a white solid (28.2 mg, 70\%, m.p.: 83-84 $\left.{ }^{\circ} \mathrm{C}\right) .{ }^{1} \mathrm{H}-\mathrm{NMR}:(\delta) 11.15(1 \mathrm{H}, \mathrm{bs}, \mathrm{NH}), 7.46(1 \mathrm{H}$, $\mathrm{s}, \mathrm{H}-6), 4.54(1 \mathrm{H}, \mathrm{t}, \mathrm{OH}, J=5.5 \mathrm{~Hz}), 4.40(2 \mathrm{H}, \mathrm{t}, 2 \times \mathrm{OH}, J=5.2 \mathrm{~Hz}), 3.69(2 \mathrm{H}, \mathrm{t}, \mathrm{H}-1$ ", $J=7.6 \mathrm{~Hz})$, 3.45 (2H, q, H-2', $J=6.3 \mathrm{~Hz}), 3.42-3.32$ (4H, m, H-4"), $2.32\left(2 \mathrm{H}, \mathrm{t}, \mathrm{H}-1^{\prime}, J=6.7 \mathrm{~Hz}\right), 1.55$ (2H, q, H-2", $J=7.3 \mathrm{~Hz}), 1.47$ (1 H, m, H-3", $J=5.9 \mathrm{~Hz})$ ppm. ${ }^{13} \mathrm{C}-\mathrm{NMR}:(\delta) 164.5(\mathrm{C}-4), 151.2(\mathrm{C}-2), 142.9$ (C-6), 109.3 (C-5), 61.9 (C-4"), 59.9 (C-2'), 46.2 (C-1"), 41.2 (C-3"), 30.4 (C-1'), 28.2 (C-2") ppm. MS 
(ESI): $m / z=259.1\left([M+\mathrm{H}]^{+}\right)$. Anal. Calcd for $\mathrm{C}_{11} \mathrm{H}_{18} \mathrm{~N}_{2} \mathrm{O}_{5}: \mathrm{C}, 51.15 ; \mathrm{H}, 7.02 ; \mathrm{N}, 10.85$. Found: C, $51.10 ; \mathrm{H}, 6.99 ; \mathrm{N}, 10.89$.

5-(3-Hydroxypropyl)-N-1-[4-hydroxy-(3-hydroxymethyl)butyl]pyrimidin-2,4-dione (32). The synthesis of $\mathbf{3 2}$ was performed in the same way as described for 31. The reagents used were: compound $\mathbf{3 0}$ (204 $\mathrm{mg}$, $0.49 \mathrm{mmol})$ and $1 \mathrm{M} \mathrm{NaOH}(5 \mathrm{~mL})$. After column chromatography $\left(\mathrm{CH}_{2} \mathrm{Cl}_{2}-\mathrm{CH}_{3} \mathrm{OH}=5: 1\right)$ compound 32 was obtained as white crystals $\left(110 \mathrm{mg}, 82 \%\right.$, m.p.: $\left.113-114{ }^{\circ} \mathrm{C}\right) .{ }^{1} \mathrm{H}-\mathrm{NMR}:(\delta) 11.14(1 \mathrm{H}, \mathrm{s}, \mathrm{NH})$, 7.46 (1H, s, H-6), 4.43-4.38 (3H, m, OH), 3.70 (2H, t, H-1", $J=7.3$ Hz), 3.46-3.30 (6H, m, H-4",

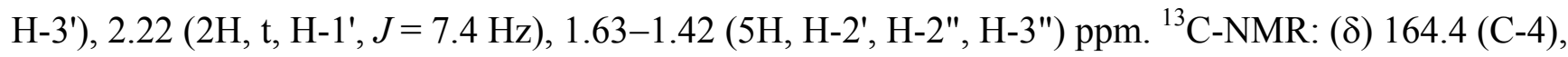
151.2 (C-2), 141.9 (C-6), 113.0 (C-5), 61.9 (C-4"), 60.6 (C-3'), 46.2 (C-1"), 41.2 (C-3"), 31.9 (C-2'), 28.3 (C-2"), $23.3\left(\mathrm{C}-1^{\prime}\right)$ ppm. MS (ESI): $m / z=273.2\left([M+\mathrm{H}]^{+}\right)$. Anal. Calcd for $\mathrm{C}_{12} \mathrm{H}_{20} \mathrm{~N}_{2} \mathrm{O}_{5}: \mathrm{C}, 52.93$; H, 7.40; N, 10.29. Found: C, 52.97; H, 7.43; N, 10.33 .

\subsection{Phosphorylation Assay of 19, 21, 23, 31 and $\mathbf{3 2}$}

\subsubsection{Protein Expression}

The HSV-1 TK was expressed in E. coli as a GST-TK fusion protein and further purified as HSV-1 TK-GST protein by using glutathione affinity chromatography following protocols that have been reported previously [33]. The human thymidine kinase 1 (hTK) was expressed in E. coli as a 6xHisTagged protein and purified following the previously published protocol [34].

\subsubsection{HPLC System and Conditions}

The high liquid performance chromatography system used Merck HITACHI LaChrom (Gynkotek HPLC, Münich, Germany) equipped with a pump (L-7100), autosampler (L-7200) and a UV detector (L-7400). The analyses were performed on an LiChroCART ${ }^{\circledR} 250-4$ cartridge column packed with a stationary phase made of spherical partical of silica (LiCrospher ${ }^{\circledR} 100 \mathrm{RP}-18$ endcapped, $(5 \mu \mathrm{m})$ ) and coupled with a guard column LiChroCART® ${ }^{\circledR}-4$ of the same type (Merck, KGaA, Darmstadt, Germany). Mobile phase consisted of $200 \mathrm{mM} \mathrm{NaH} \mathrm{PO}_{4}, 25 \mathrm{mM}$ tetrabutylammonium hydrogen sulfate (TBAHS) as the ion-pairing reagent and 0.5\% methanol (HPLC grade). All aqueous solutions were prepared using de-ionized water from Millipore. The column was kept at a constant temperature of $20{ }^{\circ} \mathrm{C}$. The separation was performed isocratically at a flow-rate of $1.1 \mathrm{~mL} / \mathrm{min}$ and the UV detection was done at $254 \mathrm{~nm}[32]$.

\subsubsection{The Phosphorylation Reaction}

Phosphorylation of dT and compounds 19, 21, 23, 31, fluorinated derivative of 31 and 32 was monitored by HPLC. Reactions were carried out in a final volume of $70 \mu \mathrm{L}$ containing $50 \mathrm{mM}$ HEPES $\mathrm{pH} 7.5,5 \mathrm{mM}$ ATP, $5 \mathrm{mM} \mathrm{MgCl} 2,1 \mathrm{mM}$ solution of dT and tested compounds and either $11 \mu \mathrm{g}$ of purified HSV-1 TK-GST or $0.8 \mu \mathrm{g}$ of hTK. As the solutions of dT and tested compounds were prepared with $100 \%$ DMSO attention was paid for not adding more than 5\% DMSO in the sample reaction (the final concentration of DMSO was $1 \%$ ). The reaction was started with the addition of HSV-1 TK-GST. The reaction was done at $37^{\circ} \mathrm{C}$ and was stopped after 30,60 and 90 min by a 10-fold 
dilution with $50 \mathrm{mM}$ EDTA (final concentration $5 \mathrm{mM}$ ) used to chelate the cofactor $\mathrm{Mg}^{2+}$. Each reaction was done in triplicate. Finally, a volume of $40 \mu \mathrm{L}$ of the sample reaction was injected for analysis. The formation of the nucleotide monophosphate was monitored qualitatively. Two different blank reactions (no enzyme or no compound) were performed under the same experimental conditions to account for the background ATP hydrolysis. Control reactions were stopped after 30, 60 and $90 \mathrm{~min}$ (Supplementary Materials). The resulting ADP/ATP ratios were calculated and used as a measure for protein activity. The mean of at least triplicate measurements are reported.

\subsubsection{Cellular Activity Evaluations}

The WI38 (normal diploid human fibroblasts) cell lines were cultured as monolayers and maintained in Dulbecco's modified Eagle medium (DMEM) supplemented with $10 \%$ fetal bovine serum (FBS), $2 \mathrm{mM}$ L-glutamine, $100 \mathrm{U} / \mathrm{mL}$ penicillin and $100 \mu \mathrm{g} / \mathrm{mL}$ streptomycin in a humidified atmosphere with $5 \% \mathrm{CO}_{2}$ at $37{ }^{\circ} \mathrm{C}$. The panel cell lines were inoculated onto a series of standard 96-well microtiter plates on day 0 , at 3000 cells to 6000 cells per well according to the doubling times of specific cell line. Test agents were then added in five, 10 -fold dilutions $\left(1 \times 10^{-8}\right.$ to $\left.1 \times 10^{-4} \mathrm{M}\right)$ and incubated for further $72 \mathrm{~h}$. Working dilutions were freshly prepared on the day of testing in the growth medium. The solvent (DMSO) was also tested for eventual inhibitory activity by adjusting its concentration to be the same as in the working concentrations (DMSO concentration never exceeded $0.1 \%)$. After $72 \mathrm{~h}$ of incubation, the cell growth rate was evaluated by performing the MTT assay: experimentally determined absorbance values were transformed into a cell percentage growth (PG) using the formulas proposed by $\mathrm{NIH}$ and described previously [35].This method directly relies on control cells behaving normally at the day of assay because it compares the growth of treated cells with the growth of untreated cells in control wells on the same plate - the results are therefore a percentile difference from the calculated expected value. The $\mathrm{IC}_{50}$ and $\mathrm{LC}_{50}$ values for each compound were calculated from dose-response curves using linear regression analysis by fitting the mean test concentrations that give PG values above and below the reference value. If, however, all of the tested concentrations produce PGs exceeding the respective reference level of effect (e.g., PG value of 50) for a given cell line, the highest tested concentration is assigned as the default value (in the screening data report that default value is preceded by a ">" sign). Each test point was performed in quadruplicate in three individual experiments. The results were statistically analyzed (ANOVA, Tukey post-hoc test at $p<0.05$ ). Finally, the effects of the tested substances were evaluated by plotting the mean percentage growth for each cell type in comparison to control on dose-response graphs.

\section{Conclusions}

5-(2-Hydroxyethyl)- and 5-(3-hydroxypropyl)-substituted 4-methoxypyrimidin-2-ones (10 and 14-16) were prepared by an efficient synthetic route and subjected to N-1 alkylation to obtain target compounds bearing 2,3-dihydroxypropyl (19), acyclovir- (21), ganciclovir- (23), and penciclovir-like side chains (compounds 31, 32). The two synthetic methods A and B that were applied for $\mathrm{N}$-alkylation indicated that method A using activated $\mathrm{N}$-anionic 5-substituted pyrimidine derivatives was more successful than the silylation reaction method. 
The influence of the acyclic glycone in target compounds 19, 21, 23, 31 and 32 on their phosphorylation ability was observed. Thereby, 5-substituted pyrimidine derivatives $\mathbf{3 1}$ and $\mathbf{3 2}$ bearing N-1 penciclovir-like side chain revealed to be substrates of HSV-1 TK. The structural congener of 31 bearing an oxygen isosteric replacement of methylene group in side chain of $\mathbf{2 3}$ was not phosphorylated by HSV-1 TK. Moreover, 5-(2-hydroxyethyl)pyrimidin-2,4-dione 31 showed to be a better substrate when compared to compound $\mathbf{3 2}$ with a longer substituent bearing an additional methylene group.

Besides, both compounds $\mathbf{3 1}$ and $\mathbf{3 2}$ exhibited no cytotoxic effect against normal human fibroblasts up to $100 \mu \mathrm{M}$. Compound $\mathbf{3 1}$ has been selected as a lead compound for development as a new PET probe for imaging HSV-1 TK expression. Therefore, the fluorine-18 radiolabeling of the corresponding pyrimidine precursor of $\mathbf{3 1}$ and the subsequent in vivo PET studies are currently underway.

\section{Supplementary Materials}

Supplementary Materials containing HPLC chromatograms of phosphorylation reaction of compounds 19, 21 and 23 with HSV-1 TK and hTK, and HPLC chromatograms for time conversion (30, 60 and 90 min of incubation) in phosphorylation of dT, 31 and its fluorinated derivative, as well as blank reactions (no enzyme or no substrate) can be accessed at: http://www.mdpi.com/1420-3049/ $18 / 5 / 5104 / \mathrm{s} 1$.

\section{Acknowledgments}

This study was performed in the framework of the SCOPES 2009-2012 programme (Swiss National Science Foundation). Support of this study by the Ministry of Science, Education and Sports of the Republic of Croatia (Project \#125-0982464-2925) is also gratefully acknowledged. We thank Sandra Kraljević-Pavelić, Ivana Ratkaj and Mirela Sedić in performing the cellular activity evaluations of 17-32.

\section{Conflict of Interest}

The authors declare no conflict of interest.

\section{References}

1. Christopherson, R.I.; Lyons, S.D.; Wilson, P.K. Inhibitors of de novo nucleotide biosynthesis as drugs. Acc. Chem. Res. 2002, 35, 961-971.

2. Blackburn, G.M. Nucleosides and Nucleotides. In Nucleic Acids in Chemistry and Biology, 3rd ed.; Blackburn, G.M., Gait, M.J., Loakes, D., Williams, D.M., Eds.; Royal Society of Chemistry: Cambridge, UK, 2006; pp. 125-136.

3. Schaeffer, J.H.; Beauchamp, L.; de Miranda, P.; Elion, G.; Bauer, D.J.; Collins, P. 9-(2-Hydroxyethoxymethyl)guanine activity against viruses of the herpes group. Nature 1978, $292,583-585$. 
4. Elion, G.B.; Furman, P.A.; Fyfe, J.A.; de Miranda, P.; Beauchamp, L.; Schaeffer, H.J. Selectivity of action of an antiherpetic agent, 9-(2-hydroxyethoxymethyl)guanine. Proc. Natl. Acad. Sci. USA 1977, 74, 5716-5720.

5. De Clerq, E.; Field, H.J. Antiviral prodrugs: The development of successful prodrug strategies for antiviral chemotheraphy. Br. J. Pharmacol. 2006, 147, 1-11.

6. Kim, H.S.; Barak, D.; Harden, K.T.; Boyer, J.L.; Jacobson, K.A. Acyclic and cyclopropyl analogues of adenosine bisphosphate antagonists of the $\mathrm{P}_{2} \mathrm{Y}_{1}$ receptor: Structure-activity relationships and receptor docking. J. Med. Chem. 2001, 44, 3092-3108.

7. Smee, D.F.; Boehme, R.; Chernow, M.; Binko, B.P.; Matthews, T.R. Intracellular metabolism and enzymatic phosphorylation of 9-(1,3-dihydroxy-2-propoxymethyl)guanine and acyclovir in herpes simplex virus-infected and uninfected cells. Biochem. Pharmacol. 1985, 34, 1049-1056.

8. Martin, J.C.; McGee, D.P.C.; Jeffrey, G.A.; Hobbs, D.W.; Smee, D.F.; Matthews, T.R.; Verheyden, J.P.H. Synthesis and anti-herpes virus activity of acyclic 2'-deoxyguanosine analogs related to 9-[(1,3-dihydroxy-2-propoxy)methyl]guanine. J. Med. Chem. 1986, 29, 1384-1389.

9. Vere Hodge, R.A.; Perkins, R.M. Mode of action of 9-(4-hydroxy-3-hydroxymethylbut-1yl)guanine (BRL 39123) against herpes simplex virus in MRC-5 cells. Antimicrob. Agents Chemother. 1989, 33, 223-229.

10. Oldfield, E.H.; Ram, Z.; Culver, K.W.; Blaese, R.M.; de Vroom, H.L.; Anderson, W.F. Gene therapy for the treatment of brain tumors using intra-tumoral transduction with the thymidine kinase gene and intravenous ganciclovir. Hum. Gene Ther. 1993, 4, 39-69.

11. Verma, I.M.; Somia, N. Gene therapy - promises, problems and prospects. Nature 1997, 389, 239-242.

12. Freeman, S.M. Suicide gene therapy. Adv. Exp. Med. Biol. 2000, 465, 411-422.

13. Fillat, C.; Carrió, M.; Cascante, A.; Sangro, B. Suicide gene theraphy mediated by the herpes simplex virus thymidine kinase gene/ganciclovir system: Fifteen years of application. Curr. Gene Ther. 2003, 3, 13-26.

14. Shiue, G.G.; Shiue, C.-Y.; Lee, R.L.; MacDonald, D.; Hustinx, R.; Eck, S.L.; Alavi, A.A. A simplified one-pot synthesis of 9-[(3-[18F]Fluoro-1-hydroxy-2-propoxy)methyl]guanine([18F]FHPG) and 9-(4-[18F]Fluoro-3-hydroxymethylbutyl)guanine ([18F]FHBG) for gene therapy. Nucl. Med. Biol. 2001, 28, 875-883.

15. Alauddin, M.M.; Shahinian, A.; Gordon, E.M.; Bading, J.R.; Conti, P.S. Preclinical evaluation of the penciclovir analog 9-(4-[18F]fluoro-3-hydroxymethylbutyl)guanine for in vivo measurement of suicide gene expression with PET. J. Nucl. Med. 2001, 42, 1682-1690.

16. Min, J.J.; Gambhir, S.S. Gene therapy progress and prospects: Noninvasive imaging of gene therapy in living subjects. Gene Ther. 2004, 11, 115-125.

17. Degreve, B.; de Clercq, E.; Balzarini, J. Bystander effect of purine nucleoside analogues in HSV-1tk suicide gene therapy is superior to that of pyrimidine nucleoside analogues. Gene Ther. 1999, 6, 162-170.

18. Raić-Malić, S.; Johayem, A.; Ametamey, S.M.; Batinac, S.; de Clercq, E.; Folkers, G.; Scapozza, L. Synthesis, 18F-radiolabelling and biological evaluations of C-6 alkylated pyrimidine nucleoside analogues. Nucleosides Nucleotides Nucleic Acids 2004, 23, 1707-1721. 
19. Martić, M.; Pernot, L.; Westermaier, Y.; Perozzo, R.; Gazivoda Kraljević, T.; Krištafor, S.; Raić-Malić, S.; Scapozza, L.; Ametamey, S. Synthesis, crystal structure, and in vitro biological evaluation of C-6 pyrimidine derivatives: new lead structures for monitoring gene expression in vivo. Nucleosides Nucleotides Nucleic Acids 2011, 30, 293-315.

20. Krištafor, S.; Novaković, I.; Gazivoda Kraljević, T.; Kraljević Pavelić, S.; Lučin, P.; Westermaier, Y.; Scapozza, L.; Ametamey, S.M.; Raić-Malić, S. Synthetic approach to new $N$-methyl thymine derivative comprising dihydroxyisobutenyl unit as ligand for thymidine kinase of herpes simplex virus type 1 (HSV1-TK). Bioorg. Med. Chem. Lett. 2011, 21, 6161-6165.

21. Müller, U.; Martić, M.; Gazivoda-Kraljević, T.; Krištafor, S.; Ranadheera, C.; Müller, A.; Born, M.; Krämer, S.D.; Raić-Malić, S.; Ametamey, M.S. Synthesis and evaluation of a C-6 alkylated pyrimidine derivative for in vivo imaging of HSV1-TK gene expression. Nucl. Med. Biol. 2012, $39,235-246$.

22. Fissekis, J.D.; Myles, A.; Brown, G.B. Synthesis of 5-hydroxyalkylpyrimidines from lactones. J. Org. Chem. 1964, 29, 2670-2673.

23. Fissekis, J.D.; Sweet, F. Chemistry of some-5-(2-hydroxyalkyl)uracil derivatives and a synthesis of 5-vinyluracil. J. Org. Chem. 1973, 38, 264-269.

24. Denny, G.H.; Ryder, M.A. $\alpha$-(Ureidomethylene)lactones and derived 5-(hyroxyalkyl)uracils. J. Med. Chem. 1974, 17, 1230-1231.

25. Griengl, H.; Wanek, E.; Schwarz, W.; Strecher, W.; Rosenwirth, B.; de Clercq, E. 2'-Fluorinated arabinonucleosides of 5-(2-haloalkyl)uracil: Synthesis and antiviral activity. J. Med. Chem. 1987, 30, 1199-1204.

26. Yu, C.-S.; Oberdorfer, F. Synthesis of 4-O-methyl-protected 5-(2-hydroxyethyl)-2'-deoxyuridine derivatives and their nucleophilic fluorination to 5-(2-fluoroethyl)-2'-deoxyuridine. Synthesis 1999, 12, 2057-2064.

27. Hilbert, G.E.; Johnson, T.B. Researches on pyrimidines. CXVII. A method for the synthesis of nucleosides. J. Am. Chem. Soc. 1930, 52, 4489-4494.

28. Ogilvie, K.K.; Hamilton, R.G.; Gillen, M.F.; Radatus, B.K.; Smith, K.O.; Galloway, K.S. Uracil analogues of the acyclonucleoside 9-[[2-hydroxy-1-(hydroxymethyl)ethoxy]methyl]guanine (BIOLF-62). Can. J. Chem. 1984, 62, 16-21.

29. Robins, M.J.; Hatfield, P.W. Nucleic acid related compounds. 37. Convenient and high-yield syntheses of $N$-[(2-hydroxyethoxy)methyl] heterocycles as "acylic nucleoside" analogues. Can. J. Chem. 1982, 60, 547-553.

30. Brand, B.; Reese, C.B.; Song, Q.; Visintin, C. Convenient syntheses of 9-[4-hydroxy-3(hydroxymethyl)butyl]guanine (penciclovir) and 9-[4-acetoxy-3-(acetoxymethyl)butyl]2-amino9H-purine (famciclovir). Tetrahedron 1999, 55, 5239-5252.

31. Geen, G.R.; Grinter, T.J.; Kincey, P.M.; Jarvest, R.L. The effect of the C-6 substituent on the regioselectivity of $\mathrm{N}$-alkylation of 2-aminopurines. Tetrahedron 1990, 46, 6903-6914.

32. Schelling, P.; Claus, M.T.; Johner, R.; Marquez, V.E.; Schulz, G.E.; Scapozza, L. Biochemical and structural characterization of (south)-methanocarbathymidine that specifically inhibits growth of herpes simplex virus type 1 thymidine kinase-transduced osteosarcoma cells. J. Biol. Chem. 2004, 279, 32832-32838. 
33. Vogt, J.; Perozzo, R.; Pautsch, A.; Prota, A.; Schelling, P.; Pilger, B.; Folkers, G.; Scapozza, L. Schulz, G.E. Nucleoside binding site of herpes simplex type 1 thymidine kinase analyzed by X-ray crystallography. Proteins 2000, 41, 545-553.

34. Birringer, M.S.; Perozzo, R.; Kut, E.; Stillhart, C.; Surber, W.; Scapozza, L.; Folkers, G. High-level expression and purification of human thymidine kinase 1: Quaternary structure, stability, and kinetics. Protein Expr. Purif. 2006, 47, 506-515.

35. Gazivoda, T.; Raić-Malić, S.; Krištafor, V.; Makuc, D.; Plavec, J.; Bratulić, S.; Kraljević-Pavelić, S.; Pavelić, K.; Naesens, L.; Andrei, G.; et al. Synthesis, cytostatic and anti-HIV evaluations of the new unsaturated acyclic C-5 pyrimidine nucleoside analogues. Bioorg. Med. Chem. 2008, 16, 5624-5634.

Sample Availability: Samples of the compounds 1-32 are available from the authors.

(C) 2013 by the authors; licensee MDPI, Basel, Switzerland. This article is an open access article distributed under the terms and conditions of the Creative Commons Attribution license (http://creativecommons.org/licenses/by/3.0/). 